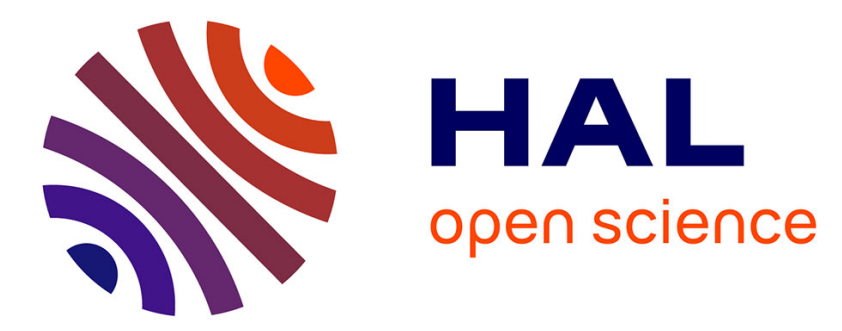

\title{
The cytoskeleton plays a modulatory role in the association between STIM1 and the Ca channel subunits Orai1 and TRPC1.
}

Carmen Galán, Natalia Dionisio, Tarik Smani, Ginés M. Salido, Juan A. Rosado

\section{To cite this version:}

Carmen Galán, Natalia Dionisio, Tarik Smani, Ginés M. Salido, Juan A. Rosado. The cytoskeleton plays a modulatory role in the association between STIM1 and the Ca channel subunits Orai1 and TRPC1.. Biochemical Pharmacology, 2011, 82 (4), pp.400. 10.1016/j.bcp.2011.05.017 . hal00718033

\section{HAL Id: hal-00718033 \\ https://hal.science/hal-00718033}

Submitted on 16 Jul 2012

HAL is a multi-disciplinary open access archive for the deposit and dissemination of scientific research documents, whether they are published or not. The documents may come from teaching and research institutions in France or abroad, or from public or private research centers.
L'archive ouverte pluridisciplinaire HAL, est destinée au dépôt et à la diffusion de documents scientifiques de niveau recherche, publiés ou non, émanant des établissements d'enseignement et de recherche français ou étrangers, des laboratoires publics ou privés. 


\section{Accepted Manuscript}

Title: The cytoskeleton plays a modulatory role in the association between STIM1 and the $\mathrm{Ca}^{2+}$ channel subunits Orai1 and TRPC1.

Authors: Carmen Galán, Natalia Dionisio, Tarik Smani, Ginés

M. Salido, Juan A. Rosado

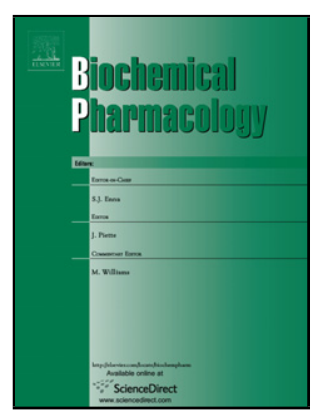

PII:

S0006-2952(11)00330-3

DOI: doi:10.1016/j.bcp.2011.05.017

Reference: BCP 10909

To appear in: $\quad B C P$

Received date: $\quad 25-2-2011$

Revised date: $\quad$ 15-5-2011

Accepted date: $\quad$ 18-5-2011

Please cite this article as: Galán C, Dionisio N, Smani T, Salido GM, Rosado JA, The cytoskeleton plays a modulatory role in the association between STIM1 and the $\mathrm{Ca}^{2+}$ channel subunits Orai1 and TRPC1., Biochemical Pharmacology (2010), doi:10.1016/j.bcp.2011.05.017

This is a PDF file of an unedited manuscript that has been accepted for publication. As a service to our customers we are providing this early version of the manuscript. The manuscript will undergo copyediting, typesetting, and review of the resulting proof before it is published in its final form. Please note that during the production process errors may be discovered which could affect the content, and all legal disclaimers that apply to the journal pertain. 
The cytoskeleton plays a modulatory role in the association between STIM1 and the $\mathrm{Ca}^{2+}$ channel subunits Orai1 and TRPC1.

Carmen Galán ${ }^{\dagger}$, Natalia Dionisio ${ }^{\dagger}$, Tarik Smani*, Ginés M. Salido ${ }^{\dagger}$, Juan A. Rosado $^{\dagger}$

${ }^{\dagger}$ Department of Physiology (Cellular Physiology Research Group), University of

Extremadura, 10071 Cáceres, and *Institute of Biomedicine from Seville, Universitary Hospital of Virgen del Rocío, University of Seville, Spain

Running head: The cytoskeleton modulates STIM1- $\mathrm{Ca}^{2+}$ channels interaction

Category: Metabolic Disorders and Endocrinology.

To whom correspondence should be addressed:

Dr. J. A. Rosado,

Department of Physiology,

University of Extremadura,

Cáceres 10003, SPAIN

Tel: +34 927257139

Fax: +34 927257110

E-mail: jarosado@unex.es 


\section{ABSTRACT}

Store-operated $\mathrm{Ca}^{2+}$ entry (SOCE) is a major pathway for $\mathrm{Ca}^{2+}$ influx in non-excitable cells. Recent studies favour a conformational coupling mechanism between the endoplasmic reticulum (ER) $\mathrm{Ca}^{2+}$ sensor STIM1 and $\mathrm{Ca}^{2+}$ permeable channels in the plasma membrane to explain SOCE. Previous studies have reported a role for the cytoskeleton modulating the activation of SOCE; therefore, here we have investigated whether the interaction between STIM1 and the $\mathrm{Ca}^{2+}$ permeable channels is modulated by the actin or microtubular network. In HEK-293 cells, treatment with the microtubular disrupter colchicine enhanced both the activation of SOCE and the association between STIM1 and Orai1 or TRPC1 induced by thapsigargin (TG). Conversely, stabilization of the microtubules by paclitaxel attenuated TGevoked activation of SOCE and the interaction between STIM1 and the $\mathrm{Ca}^{2+}$ channels Orai1 and TRPC1, altogether suggesting that the microtubules act as a negative regulator of SOCE. Stabilization of the cortical actin filament layer results in inhibition of TG-evoked both association between STIM1, Orai1 and TRPC1 and SOCE. Interestingly, disruption of the actin filament network by cytochalasin D did not significantly modify TG-evoked association between STIM1 and Orai1 or TRPC1 but enhanced TG-stimulated SOCE. Finally, inhibition of calmodulin by calmidazolium enhances TG-evoked SOCE and disruption of the actin cytoskeleton results in inhibition of TG-evoked association of calmodulin with Orai1 and TRPC1. Thus, we demonstrate that the cytoskeleton plays an essential role in the regulation of SOCE through the modulation of the interaction between their main molecular components.

Keywords: actin filaments, microtubules, calmodulin, TRPC1, STIM1, Orai1. 


\section{Introduction}

Store-operated $\mathrm{Ca}^{2+}$ entry (SOCE) is a major mechanism for $\mathrm{Ca}^{2+}$ influx into cells and plays an important role in a wide variety of cellular processes [1]. The endoplasmic reticulum (ER) $\mathrm{Ca}^{2+}$ sensor STIM1, as well as a number of $\mathrm{Ca}^{2+}$-permeable plasma membrane channels, including Orai1 and certain members of the TRPC subfamily, are key players in SOCE. STIM1 is a single-pass membrane protein that is mainly located in the ER membrane and shows different functional domains, including the luminal EF hands, that allow STIM1 to sense the intraluminal $\mathrm{Ca}^{2+}$ concentration [2-3], the Orai1 interaction domain (SOAR/CAD) [4-6], the CRAC modulatory domain (CMD) [7] and the STIM1 homomerization domain (SHD) [8], among others. When $\mathrm{Ca}^{2+}$ stores are full STIM1 remains in an inactive state through an intramolecular shielding of the SOAR/CAD domain that prevents constitutive SOCE [8]. However, discharge of the ER results in dissociation of $\mathrm{Ca}^{2+}$ from the EF-hand domains, thus resulting in the activation of the store-operated channels (SOCs) Orai1 and TRPCs. The coupling between STIM1 and Orai1 involves the interaction of SOAR domain positive charges with the acidic domain within the Orai1 C-terminal domain in order to activate the channel [9-10]. On the other hand, STIM1 has been shown to interact and gate TRPC members, such as TRPC1, through electrostatic interaction between STIM1(K684,K685) and TRPC1(D639,D640) [11].

Recent studies in HEK293 cells have reported that, while oligomerization of STIM1 is independent on the microtubular network, the distribution of STIM1 in the ER requires the integrity of the microtubules, which facilitate STIM1 movements [12]; thus providing evidence for a role of the cytoskeleton in the regulation of SOCE in these cellular model. A number of studies have investigated the regulation of SOCE by the cytoskeleton, including the actin microfilaments and the microtubules, with different results depending on the cell 
type. In NIH $3 \mathrm{~T} 3$ fibroblasts and smooth muscle DT40 cells inhibition of actin polymerization with cytochalasin or depolymerisation of the microtubular network with nocodazole does not significantly alter SOCE [13-16], thus suggesting that in these cells the cytoskeleton is not essential for the activation of SOCE. In contrast, in human platelets, which have a more evenly distributed cytoskeleton, impairment of actin filaments and microtubules remodelling either by inhibition of polymerization or by stabilization results in inhibition of SOCE [17-19] and a similar functional role has been described for the actin cytoskeleton in endothelial cells [20] and pancreatic acinar cells [21]. In human platelets we have more recently reported that store depletion results in an initial decrease in the actin filament content, probably due to disorganization of the cortical actin network to facilitate the interaction between proteins in the ER and plasma membrane, followed by an increase in actin polymerization necessary for the intracellular trafficking of portions of the ER towards the plasma membrane [22]. Therefore, we have explored the functional relevance of the cytoskeleton in the association between STIM1 and the SOC components Orai1 and TRPC1 upon depletion of the intracellular $\mathrm{Ca}^{2+}$ stores in HEK-293 cells endogenously expressing these proteins. 


\section{Materials and methods}

\subsection{Materials}

Fura-2/AM and Oregon Green 488 paclitaxel were from Invitrogen (Madrid, Spain). Bovine serum albumin (BSA), sodium dodecyl sulfate (SDS), Fluorescein isothiocyanate (FITC) conjugated phalloidin, Tris, triton X-100, phenyl methyl sulfonyl fluoride, leupeptin, benzamidin, deoxycholate, thapsigargin (TG), probenecid, Nonidet P-40, formaldehyde, calmidazolium, colchicine and paclitaxel (Taxol) were from Sigma (Madrid, Spain). Cytochalasin D (Cyt D) and jasplakinolide were from Calbiochem (Madrid, Spain). Dulbecco's modified Eagle's medium and heat-inactivated fetal bovine serum were from Sanex (Badajoz, Spain). Mouse anti-STIM1 antibody (25-139) was from BD Transduction Laboratories (Frankin Lakes, NJ, USA). Rabbit anti-hTRPC1 polyclonal antibody (557-571) was obtained from Alomone Laboratories (Jerusalem, Israel). Rabbit anti-Orai1 polyclonal antibody $\mathrm{N}$ terminal was from ProSci Inc (Derio, Bizkaia, Spain). Mouse anti-calmodulin antibody was from Abcam (Cambridge, UK). Donkey anti-rabbit IgG horseradish peroxidase-conjugated, sheep anti-mouse IgG horseradish peroxidase-conjugated, blotting paper and photographic films were from GE Healthcare (Madrid, Spain). Protein A-agarose was from Upstate Biotechnology Inc (Waltham, MA, USA). Enhanced chemiluminiscence detection reagents was from Pierce (Cheshire, UK). Hyperfilm ECL was from Amersham (Buckinghamshire, UK). All other reagents were of analytical grade.

\subsection{Cell culture}

Human embryonic kidney 293 (HEK293) cells were obtained from the American Type Culture Collection (Barcelona, Spain) and cultured in Dulbecco's modified Eagle's medium, 
supplemented with $10 \%$ heat-inactivated fetal bovine serum, in a $37{ }^{\circ} \mathrm{C}$ incubator with $5 \%$ $\mathrm{CO}_{2}$. At the time of the experiments cells were suspended in HEPES-buffered saline (HBS) containing (in mM): $145 \mathrm{NaCl}, 10 \mathrm{HEPES}, 10 \mathrm{D}$-glucose, $5 \mathrm{KCl}, 1 \mathrm{MgSO}_{4}, 1 \mathrm{mM} \mathrm{CaCl}$, $\mathrm{pH}$ 7.45. When a $\mathrm{Ca}^{2+}$-free medium was required $1.2 \mathrm{mM}$ EGTA was added.

\subsection{Measurement of intracellular free calcium concentration $\left(\left[\mathrm{Ca}^{2+}\right]_{c}\right)$}

HEK293 cells were suspended and loaded with fura- 2 by incubation with $2 \mu \mathrm{M}$ fura2/AM and $2.5 \mathrm{mM}$ probenecid for $30 \mathrm{~min}$ at $37^{\circ} \mathrm{C}$. Fluorescence was recorded from $2 \mathrm{~mL}$ aliquots of magnetically stirred cellular suspension $\left(2 \times 10^{6}\right.$ cells $\left./ \mathrm{mL}\right)$ at $37^{\circ} \mathrm{C}$ using a Cary Eclipse spectrophotometer (Varian Ltd, Madrid, Spain) with excitation wavelengths of 340 and $380 \mathrm{~nm}$ and emission at $505 \mathrm{~nm}$. Changes in $\left[\mathrm{Ca}^{2+}\right]_{\mathrm{c}}$ were monitored using the fura-2 $340 / 380$ fluorescence ratio and calibrated in terms of $\left[\mathrm{Ca}^{2+}\right]_{\mathrm{c}}[23]$.

$\mathrm{Ca}^{2+}$ release by TG was estimated using the integral of the rise in $\left[\mathrm{Ca}^{2+}\right]_{\mathrm{c}}$ for 3 min after the addition of the agonist. $\mathrm{Ca}^{2+}$ entry into TG-treated cells upon addition of $\mathrm{Ca}^{2+}$ to the extracellular medium was estimated using the integral of the rise in $\left[\mathrm{Ca}^{2+}\right]_{\mathrm{c}}$ for $3 \mathrm{~min}$ after addition of $\mathrm{CaCl}_{2}\left(\int \Delta\left[\mathrm{Ca}^{2+}\right]_{\mathrm{c}} \mathrm{dt}\right)$, normalized taking a sample every second, and expressed as nM•s $[24-26] . \mathrm{Ca}^{2+}$ entry was corrected by subtraction of the $\left[\mathrm{Ca}^{2+}\right]_{\mathrm{c}}$ elevation due to leakage of the indicator to eliminate interferences due to extracellular fura-2.

\subsection{Immunoprecipitation and Western blotting}

The immunoprecipitation and Western blotting were performed as described previously [27]. Briefly, Cell suspension aliquots $\left(500 \mu \mathrm{L} ; 2 \times 10^{6}\right.$ cells $\left./ \mathrm{mL}\right)$ were treated as described and lysed with lysis buffer, $\mathrm{pH}$ 7.2, containing $316 \mathrm{mM} \mathrm{NaCl}, 20 \mathrm{mM}$ Tris, $2 \mathrm{mM}$ EGTA, $0.2 \%$ SDS, $2 \%$ sodium deoxycholate, $2 \%$ triton $\mathrm{X}-100,2 \mathrm{mM}$ phenyl methyl sulfonyl fluoride, $100 \mu \mathrm{g} / \mathrm{mL}$ leupeptin and $10 \mathrm{mM}$ benzamidine. Samples were immunoprecipitated 
by simultaneous incubation with $2 \mu \mathrm{g}$ of anti-STIM1 antibody and protein A-agarose overnight at $4{ }^{\circ} \mathrm{C}$ on a rocking platform. Proteins were separated by $10 \%$ SDS-PAGE and electrophoretically transferred, for $2 \mathrm{~h}$ at $0.8 \mathrm{~mA} / \mathrm{cm}^{2}$, in a semi-dry blotter (Hoefer Scientific, Newcastle, Staffs., U.K.) onto nitrocellulose membranes for subsequent probing. Blots were incubated overnight with $10 \%$ (w/v) BSA in Tris-buffered saline with $0.1 \%$ Tween 20 (TBST) to block residual protein binding sites. Immunodetection of Orail, hTRPC1, calmodulin and STIM1 was achieved using the anti-Orai1, anti-calmodulin or antiSTIM1 antibodies diluted 1:1000 in TBST for $2 \mathrm{~h}$ or the anti-hTRPC1 antibody diluted 1:200 in TBST for $2 \mathrm{~h}$. To detect the primary antibody, blots were incubated for $1 \mathrm{~h}$ with the appropriate horseradish peroxidase-conjugated anti-IgG antibody diluted 1:10000 in TBST and then exposed to enhanced chemiluminescence reagents for $5 \mathrm{~min}$. Blots were then exposed to photographic films. The density of bands on the film was measured using Image $\mathbf{J}$ (Windows version; National Institutes of Health) [28].

To assess the specificity of the bands we performed primary controls and primary-free controls, where whole cell lysates $\left(2 \times 10^{6}\right.$ cells $\left./ \mathrm{mL}\right)$ were subjected to $10 \%$ SDS/PAGE and proteins were electrophoretically transferred onto membranes for incubation with primary and subsequently secondary antibody (primary control) or incubation solely with secondary antibody (primary-free control).

\subsection{Measurement of F-actin Content}

The F-actin content was determined according to a previously published procedure [22]. Briefly, samples of cell suspensions ( $200 \mu \mathrm{L} ; 2 \times 10^{6}$ cells $/ \mathrm{mL}$ ) were transferred to $200 \mathrm{~mL}$ of ice-cold 3\% (w/v) formaldehyde in phosphate-buffered saline (PBS; composition, in mM: $\mathrm{NaCl}$ 137, $\mathrm{KCl}$ 2.7, $\mathrm{Na}_{2} \mathrm{HPO}_{4} 4.3, \mathrm{KH}_{2} \mathrm{PO}_{4}$ 1.4, $\mathrm{pH}$ 7.3) for 10 min. Fixed cells were permeabilized by incubation for 10 min with $0.025 \%$ (v/v) Nonidet P-40 detergent dissolved 
in PBS. Cells were then incubated for $30 \mathrm{~min}$ with $1 \mu \mathrm{M}$ FITC-labeled phalloidin in PBS supplemented with $0.5 \%(\mathrm{w} / \mathrm{v})$ BSA. Cells were collected by centrifugation and resuspended in PBS. Cell staining was measured using a Perkin-Elmer fluorescence spectrophotometer (Perkin-Elmer, Norwalk, CT). Samples were excited at $496 \mathrm{~nm}$, and emission was at $516 \mathrm{~nm}$.

\subsection{Measurement of microtubular content}

The microtubular content was determined following a previously published procedure [29]. Briefly, samples of cell suspensions $\left(200 \mu \mathrm{L} ; 2 \times 10^{6}\right.$ cells $\left./ \mathrm{mL}\right)$ were transferred to 200 $\mu \mathrm{l}$ of ice-cold 3\% (w/v) formaldehyde in PBS for $10 \mathrm{~min}$. Fixed cells were permeabilized by incubation for 10 min with $0.025 \%$ (v/v) Nonidet P40 detergent dissolved in PBS and then incubated for 30 min with Oregon Green 488 paclitaxel $(1 \mu \mathrm{M})$ in PBS supplemented with $0.5 \%(\mathrm{w} / \mathrm{v})$ BSA. Cells were collected by centrifugation and resuspended in PBS. Cell staining was measured using a Perkin-Elmer fluorescence spectrophotometer (Perkin-Elmer, Norwalk, CT). Samples were excited at $488 \mathrm{~nm}$ and emission was at $522 \mathrm{~nm}$.

\subsection{Statistical Analysis}

Analysis of statistical significance was performed using one-way analysis of variance combined with the Dunnett tests. The difference was considered statistically significant when at least $p<0.05$. 


\section{Results}

\subsection{The microtubules regulate TG-evoked SOCE and association between STIM1, Orail and TRPCI}

In the absence of extracellular $\mathrm{Ca}^{2+}$, the addition of $1 \mu \mathrm{M}$ TG to fura-2-loaded HEK-293 cells in stirred cuvettes at $37^{\circ} \mathrm{C}$ evoked a transient elevation in $\left[\mathrm{Ca}^{2+}\right]_{\mathrm{c}}$ due to the release of $\mathrm{Ca}^{2+}$ from intracellular stores. Subsequent addition of $2 \mathrm{mM} \mathrm{Ca}^{2+}$ to the external medium induced a sustained increase in $\left[\mathrm{Ca}^{2+}\right]_{\mathrm{c}}$ indicative of SOCE (the integral of the TG-evoked rise in $\left[\mathrm{Ca}^{2+}\right]_{\mathrm{c}}$ for 3 min after addition of $\mathrm{CaCl}_{2}$ was $15327 \pm 1221 \mathrm{nM} \bullet$; Fig. 1A). Treatment of HEK-293 cells with $1 \mu \mathrm{M}$ TG resulted in association of Orai1 and TRPC1 with STIM1. Although the interaction of STIM1 with these two channels was detected in resting conditions, stimulation with TG enhanced the interaction between STIM1 and both Orail and TRPC1 by $75 \pm 9 \%$ and $80 \pm 11 \%$, respectively (Figs. $1 \mathrm{~B}$ and C; $p<0.05 ; n=6$ ).

We have investigated the role of microtubules in the activation of SOCE in HEK-293 cells and the interaction between STIM1, Orail and TRPC1 controlled by depletion of the intracellular stores by using colchicine, a tubulin microtubule disrupting agent [29-30], and paclitaxel that induces microtubular stabilization and increases the cellular microtubular content [31-32]. Treatment with $30 \mu \mathrm{M}$ colchicine for $30 \mathrm{~min}$ at $37^{\circ} \mathrm{C}$ significantly reduced the microtubular content in non-stimulated cells, as well as abolished tubulin polymerisation after stimulation with $1 \mu \mathrm{M}$ TG (Table $1 ; p<0.05 ; \mathrm{n}=6$ ). Cell treatment with colchicine enhanced TG-evoked SOCE by $23 \pm 4 \%$ (the integral of the TG-evoked rise in $\left[\mathrm{Ca}^{2+}\right]_{\mathrm{c}}$ for 3 min after addition of $\mathrm{CaCl}_{2}$ in cells pretreated with colchicine was $18975 \pm 543 \mathrm{nM} \bullet$ s; $p<0.05$ ), without having any effect on TG-evoked $\mathrm{Ca}^{2+}$ release from the intracellular stores (Fig. 1A). We further investigated the effect of treatment with colchicine on TG-induced 
association between STIM1 and both Orai1 and TRPC1. As shown in Figs. 1B and C, top panels, treatment with colchicine enhanced TG-evoked association between STIM1 and Orai1 by $75 \pm 9 \%$ and between STIM1 and TRPC1 by $44 \pm 6 \%(p<0.05)$, without affecting the association between these proteins in non-stimulated cells $(n=6)$. Western blotting with the immunoprecipitating antibody confirms that a similar amount of protein was loaded in all lanes (Figs. 1B and C, bottom panels). Conversely, treatment of HEK-293 cells for 30 min with $10 \mu \mathrm{M}$ paclitaxel at $37{ }^{\circ} \mathrm{C}$ enhanced the microtubular content in non-stimulated cells and prevented TG-evoked tubulin polymerisation (Table $1 ; p<0.05 ; \mathrm{n}=6$ ). Treatment with paclitaxel attenuated TG-evoked SOCE by $60 \pm 7 \%$ (the integral of TG-evoked rise in $\left[\mathrm{Ca}^{2+}\right]_{\mathrm{c}}$ for 3 min after addition of $\mathrm{CaCl}_{2}$ in cells pretreated with paclitaxel was $6238 \pm 1508$

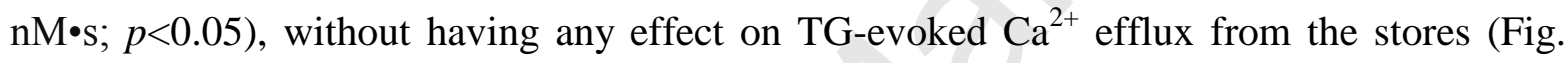
2A). In addition, pretreatment with paclitaxel reduced TG-induced association between STIM1 and both Orai1 and TRPC1 by $49 \pm 6 \%$ and $59 \pm 5 \%$, respectively $(p<0.05)$, without affecting the interaction between these proteins in non-stimulated cells (Figs. 2B and C, top panels; $n=6$ ). Western blotting with the immunoprecipitating antibody confirms that a similar amount of protein was loaded in all lanes (Figs. 2B and C, bottom panels).

\subsection{Jasplakinolide inhibits TG-evoked SOCE and association between STIM1, Orail and TRPC1}

Jasplakinolide, a cell-permeant peptide isolated from Jaspis johnstoni, induces polymerization and stabilization of actin filaments underneath the plasma membrane [33]; therefore, it is a useful tool to explore the role of the cortical actin cytoskeleton in the activation of SOCE and its relevance in the association between STIM1 and the $\mathrm{Ca}^{2+}$ channels in the plasma membrane. Cell treatment for 30 min with $10 \mu \mathrm{M}$ jasplakinolide at 37 ${ }^{\circ} \mathrm{C}$ resulted in a significant increase in the F-actin content in non-stimulated cells and 
prevented TG-induced further actin filament polymerisation (Table $2 ; p<0.05 ; \mathrm{n}=6$ ). Treatment with jasplakinolide attenuated SOCE by $67 \pm 7 \%$ (the integral of TG-evoked rise in $\left[\mathrm{Ca}^{2+}\right]_{\mathrm{c}}$ for 3 min after addition of $\mathrm{CaCl}_{2}$ in cells pretreated with jasplakinolide was $5118 \pm$ $1867 \mathrm{nM} \bullet \mathrm{s} ; p<0.05$ ), without having any effect on TG-evoked $\mathrm{Ca}^{2+}$ release from the intracellular stores (Fig. 3A). In cells treated with jasplakinolide TG was unable to enhance association between STIM1 and both Orail and TRPC1 (Figs. 3B and C, top panels; $p<0.05)$. Treatment with jasplakinolide did not affect the interaction between these proteins in cells not treated with TG (Figs. 3B and C, top panels). Western blotting with the antiSTIM1 antibody confirms a similar amount of protein loaded in all lanes (Figs. 3B and C, bottom panels).

\subsection{Disruption of the actin cytoskeleton enhances TG-evoked SOCE}

In order to investigate the role of the actin filament network in SOCE and TG-evoked association between STIM1 and the $\mathrm{Ca}^{2+}$ channels Orail and TRPC1, we used Cyt D, a widely utilized cell-permeant inhibitor of actin polymerization [17, 34]. Pretreatment of HEK-293 cells for 40 min at $37^{\circ} \mathrm{C}$ with $10 \mu \mathrm{M}$ Cyt D reduced the F-actin content in nonstimulated cells and impaired TG-induced F-actin polymerisation (Table $2 ; p<0.05 ; \mathrm{n}=6$ ). In addition, treatment with Cyt D enhanced TG-evoked $\mathrm{Ca}^{2+}$ entry by $71 \pm 5 \%$ (the integral of the rise in $\left[\mathrm{Ca}^{2+}\right]_{\mathrm{c}}$ for 3 min after addition of $\mathrm{CaCl}_{2}$ was $25190 \pm 1780 \mathrm{nM} \bullet \mathrm{s}$ in Cyt D-treated cells, Fig. $4 \mathrm{~A} ; \quad p<0.05 ; n=6)$. In contrast to the effect of Cyt D on TG-evoked $\mathrm{Ca}^{2+}$ entry, treatment of HEK-293 cells with $10 \mu \mathrm{M}$ Cyt D for $40 \mathrm{~min}$ at $37{ }^{\circ} \mathrm{C}$ did not significantly modify the association between STIM1 and both Orai1 and TRPC1 in non-stimulated cells or cells treated with TG (Fig. 4B and 4C, top panels). Western blotting with the immunoprecipitating antibody confirms a similar amount of protein loaded in all lanes (Figs. 4B and $\mathrm{C}$, bottom panels). 
3.4. Cytochalasin D impaires TG-stimulated association of calmodulin with Orail and TRPC1.

Calmodulin has been previously reported to modulate $\mathrm{Ca}^{2+}$ signals and to interact with TRPC1 [35] and Orai1 [36]. Since disruption of the actin filament network by treatment with Cyt D reported different effects on TG-evoked SOCE and TG-evoked association between STIM1 and the $\mathrm{Ca}^{2+}$ channels, we further investigated the possible regulation of the association between calmodulin and the $\mathrm{Ca}^{2+}$ channels upon treatment with $\mathrm{Cyt} \mathrm{D}$. In a medium containing $1 \mathrm{mM} \mathrm{Ca}{ }^{2+}$, TG enhances the association between calmodulin and both Orai1 and TRPC1 proteins by $215 \pm 47 \%$ and $121 \pm 27 \%$, respectively (Figs. 5A and B, top panels; $p<0.05 ; n=6)$. Treatment of HEK-293 cells for 40 min with $10 \mu \mathrm{M}$ Cyt D did not significantly modify the association between calmodulin and the channel proteins in nonstimulated cells but abolished TG-evoked responses (Figs. 5A and B, top panels; $p<0.05$; $n=6)$. Western blotting with the immunoprecipitating antibody confirms a similar amount of protein loaded in all lanes (Figs. 5A and B, bottom panels). In order to investigate whether TG-evoked $\mathrm{Ca}^{2+}$ release from the stores is sufficient to activate association between calmodulin and the $\mathrm{Ca}^{2+}$ channel proteins Orail and TRPC1, we repeated the experiments in a $\mathrm{Ca}^{2+}$-free medium. In the absence of extracellular $\mathrm{Ca}^{2+}$ treatment with TG significantly enhanced Orai1-calmodulin and TRPC1-calmodulin interaction by $169 \pm 26 \%$ and $45 \pm 10 \%$, respectively, as detected by co-immunoprecipitation (Figs. 5C and D, top panels; $p<0.05$; $n=6)$. TG-induced association between calmodulin and both Orai1 and TRPC1 was significantly greater when the experiments were performed in a medium containing $1 \mathrm{mM}$ $\mathrm{Ca}^{2+}$, which allowed $\mathrm{Ca}^{2+}$ to enter (Fig. 5, top panels; $p<0.05$ ). TG-evoked association between calmodulin and both Orai1 and TRPC1 was abolished by treatment with Cyt D (Figs. 5C and D; $p<0.05 ; n=6$ ), thus suggesting that this association requires the integrity of 
the actin filament network.

Previous studies have reported that calmodulin antagonists potentiate SOCE in pulmonary artery smooth muscle cells [37], and cerebellar granule cells [38] and astrocytes [39]. Hence, we have further investigated the effect of the calmodulin antagonist calmidazolium on TGevoked $\mathrm{Ca}^{2+}$ entry in HEK-293 cells. Our results indicate that treatment for 10 min with 1 $\mu \mathrm{M}$ calmidazolium enhances TG-induced calcium entry by $63 \pm 7 \%$ (the integral of the rise in $\left[\mathrm{Ca}^{2+}\right]_{\mathrm{c}}$ for 3 min after addition of $\mathrm{CaCl}_{2}$ was $25092 \pm 356 \mathrm{nM} \bullet \mathrm{s}$ in calmidazolium-treated cells), without inducing significant changes in TG-evoked $\mathrm{Ca}^{2+}$ release (Fig. $6 ; p<0.05 ; n=6$ ). The effect of calmidazolium was similar to that observed when cells were pretreated with calmidazolium in the presence of Cyt D, which enhanced TG-evoked SOCE by $69 \pm 5 \%$ (the integral of the rise in $\left[\mathrm{Ca}^{2+}\right]_{\mathrm{c}}$ for 3 min after addition of $\mathrm{CaCl}_{2}$ was $26034 \pm 249 \mathrm{nM} \bullet \mathrm{s}$ in calmidazolium+Cyt D-treated cells; Fig. 6 ; $p<0.05$; $n=6$ ); thus indicating that the effect of Cyt D enhancing TG-evoked $\mathrm{Ca}^{2+}$ entry might be attributed to inhibition of the regulatory role of calmodulin on SOCE. 
The role of the cytoskeleton on the activation of $\mathrm{Ca}^{2+}$ entry following the depletion of intracellular $\mathrm{Ca}^{2+}$ stores is a complex signaling process of great relevance that has been investigated in a number of cells providing discrepant results. In human platelets, we have found that microtubules play a dual role in SOCE, acting as a barrier that prevents constitutive SOCE regulated by the dense tubular system, the ER analogue in platelets, and also supporting SOCE mediated by the acidic $\mathrm{Ca}^{2+}$ stores [19]. In contrast, in HEK 293 cells microtubules seems to support SOCE and $I_{\mathrm{CRAC}}$, which has been attributed to a role of the microtubules in STIM1 localization [40]. On the other hand, SOCE has been reported to be insensitive to Cyt $\mathrm{D}$, a widely used membrane-permeant inhibitor of actin polymerization, in a number of cells, such as the DDT 1 MF-2 transformed smooth muscle cell line and the nontransformed A7r5 smooth muscle line derived from rat embryonic aorta [14]. In contrast, the actin network plays an important role in SOCE in neutrophils [41], human keratinocytes [42], bovine adrenocortical fasciculata cells [43], glioma C6 cells [44], vascular endothelial cells [20] and human platelets [17-18, 45]. In the latter, we have reported a time-dependent effect of Cyt D on platelet SOCE, which is consistent with a dual role for the actin cytoskeleton in SOCE both acting as a negative clamp that prevents constitutive SOCE but also supporting the coupling between elements in the membrane of the ER and $\mathrm{Ca}^{2+}$ channels in the plasma membrane[17-18].

We have found that disruption of the actin cytoskeleton by Cyt D or treatment with the microtubule disrupting agent, colchicine, increases TG-evoked SOCE, while stabilization of the cortical actin network or the microtubules using jasplakinolide and paclitaxel, respectively, basically induced opposite effects, attenuating TG-evoked SOCE, as expected. These observations suggest that the actin cytoskeleton and microtubules play an important 
role in $\mathrm{Ca}^{2+}$ influx, probably acting as a barrier that prevents SOCE in resting cells, as reported in human platelets [19]. A previous study has reported that nocodazole and colchicine reduce TG-evoked SOCE in HEK-293 cells [40]. This apparent contradiction between our observations and those reported by Smyth and co-workers might be attributed to the fact that both studies estimate SOCE at different stages. In our study, the initiation of $\mathrm{Ca}^{2+}$ entry was induced three minutes after the addition of TG, while in the study published by Smyth and co-workers TG was added to cells suspended in a medium containing $\mathrm{Ca}^{2+}$ [40]. Different stages for SOCE have been reported in different cell types, such as pancreatic acinar cells [46] and human platelets [47], the latter differentially regulated by the cytoskeleton [48].

The role of the cytoskeleton in the modulation of SOCE has been attributed to a number of signalling events, including the facilitation of STIM1 localization within the ER [40], probably through its interaction with the microtubule-plus-end-tracking protein EB1 [49], the regulation of TRP channels internalization [41] or by modulating the interaction of TRPC proteins with the type II $\mathrm{IP}_{3}$ receptor [50-51]. Here, we report for the first time that the cytoskeleton regulates the association of STIM1 with Orai1 and the TRPC1 channels in the plasma membrane. The reported effects of the microtubule altering manoeuvres, either using colchicine or paclitaxel, or those of jasplakinolide, on SOCE are paralleled by a similar modification of the association between STIM1 and the $\mathrm{Ca}^{2+}$ channels, and suggest that both the actin filaments and microtubules act as a cortical barrier that prevents the association between STIM1 and the $\mathrm{Ca}^{2+}$ channels, as well as SOCE (see Fig. 7), thus disruption of this barrier facilitates the coupling between STIM1 and the $\mathrm{Ca}^{2+}$ channels, as well as SOCE, while stabilization of the cortical actin or microtubular networks impairs both events. However, we found that actin filament disruption enhances SOCE without inducing any 
significant effect on the association between STIM1 and Orai1 or STIM1 and TRPC1. Interestingly, we have found that microfilament disruption results in inhibition of TGinduced association between calmodulin and both Orail and TRPC1 (see Fig. 7). Since inhibition of calmodulin results in a similar increase in TG-evoked SOCE than disruption of the actin network our results provide evidence for a role of calmodulin in the regulation of SOCE through its interaction with Orail and TRPC1 supported by the actin cytoskeleton. The microtubules must play a further important regulatory role in the association of STIM1 with the $\mathrm{Ca}^{2+}$ channels as previously reported [12], since disruption of the microtubules enhances this association, an event that has not been found after inhibition of actin polymerization.

Calmodulin has been reported to interact with TRP proteins, including Drosophila TRPL [52] and mammalian TRPC1 [35]. More recently, calmodulin was found to interact with the polybasic C-termini of STIM1 [53] and with a membrane-proximal N-terminal domain of Orai1 [36] in a $\mathrm{Ca}^{2+}$ dependent manner. Different experimental manoeuvres have demonstrated that calmodulin is involved in $\mathrm{Ca}^{2+}$-dependent inactivation of SOCE, including expression of TRPC1 or Orai1 mutants lacking the ability to bind calmodulin, which prevented $\mathrm{Ca}^{2+}$-dependent inactivation of SOCE in human salivary gland cells [35], or $I_{\mathrm{CRAC}}$ in HEK-293 cells [36], respectively, or over-expression of a calmodulin inhibitor peptide and a $\mathrm{Ca}^{2+}$-insensitive calmodulin mutant, which results in reduced inactivation of $I_{\mathrm{SOC}}$ in liver cells [54]. Our results indicate that association of calmodulin with the $\mathrm{Ca}^{2+}$ channels Orai1 and TRPC1 requires the integrity of the actin cytoskeleton, which might provide a support for these associations, and, therefore, disruption of the actin network leads to impairment of $\mathrm{Ca}^{2+}$-dependent inactivation of SOCE reported above.

We have not performed experiments to assess whether the effect of the cytoskeleton 
modifiers is maximal; however, the changes induced in the microtubules and actin filaments are sufficiently evident to demonstrate that the cytoskeleton plays a relevant role in the regulation of SOCE in HEK-293 cells through the regulation of the interaction between STIM1 and Orai1 or TRPC1. In addition, the actin cytoskeleton supports the association of calmodulin with the $\mathrm{Ca}^{2+}$ channels in the plasma membrane, which provides an additional regulatory role of store-operated $\mathrm{Ca}^{2+}$ influx.

\section{Acknowledgements}

Supported by MICINN (Grants BFU2010-21043-C02-01 and BFU2010-21043-C02-02) and Junta de Extremadura- FEDER (GR10010). C.G. and N.D. are supported by Spanish Ministry of Science and Innovation (PTA2008- 0870-P) and Junta de Extremadura (PRE09020), respectively.

\section{Disclosure of conflict of interests}

The authors state that there is no conflict of interest. 


\section{References}

[1] Putney JW, Bird GS. Cytoplasmic calcium oscillations and store-operated calcium influx. J Physiol 2008;586:3055-9.

[2] Stathopulos PB, Zheng L, Li GY, Plevin MJ, Ikura M. Structural and mechanistic insights into STIM1-mediated initiation of store-operated calcium entry. Cell 2008;135:110-22.

[3] Zhang SL, Yu Y, Roos J, Kozak JA, Deerinck TJ, Ellisman MH, et al. STIM1 is a $\mathrm{Ca} 2+$ sensor that activates CRAC channels and migrates from the $\mathrm{Ca} 2+$ store to the plasma membrane. Nature 2005;437:902-5.

[4] Yuan JP, Zeng W, Dorwart MR, Choi YJ, Worley PF, Muallem S. SOAR and the polybasic STIM1 domains gate and regulate Orai channels. Nat Cell Biol 2009;11:337-43.

[5] Park CY, Hoover PJ, Mullins FM, Bachhawat P, Covington ED, Raunser S, et al. STIM1 clusters and activates CRAC channels via direct binding of a cytosolic domain to Orai1. Cell 2009;136:876-90.

[6] Muik M, Fahrner M, Derler I, Schindl R, Bergsmann J, Frischauf I, et al. A Cytosolic Homomerization and a Modulatory Domain within STIM1 C Terminus Determine Coupling to ORAI1 Channels. J Biol Chem 2009;284:8421-6.

[7] Derler I, Fahrner M, Muik M, Lackner B, Schindl R, Groschner K, et al. A CRAC modulatory domain (CMD) within STIM1 mediates fast $\mathrm{Ca} 2+-$ dependent inactivation of ORAI1 channels. J Biol Chem 2009.

[8] Yu F, Sun L, Courjaret R, Machaca K. Role of the STIM1 C-terminal domain in STIM1 clustering. J Biol Chem 2011:doi/10.1074/jbc.M110.188789.

[9] Muik M, Frischauf I, Derler I, Fahrner M, Bergsmann J, Eder P, et al. Dynamic coupling of the putative coiled-coil domain of ORAI1 with STIM1 mediates ORAI1 channel activation. J Biol Chem 2008;283:8014-22.

[10] Wang Y, Deng X, Gill DL. Calcium signaling by STIM and Orai: intimate coupling details revealed. Sci Signal 2010;3:pe42.

[11] Zeng W, Yuan JP, Kim MS, Choi YJ, Huang GN, Worley PF, et al. STIM1 gates TRPC channels, but not Orai1, by electrostatic interaction. Mol Cell 2008;32:439-48.

[12] Smyth JT, DeHaven WI, Bird GS, Putney JW, Jr. Role of the microtubule cytoskeleton in the function of the store-operated $\mathrm{Ca} 2+$ channel activator STIM1. J Cell Sci 2007;120:3762-71.

[13] Ribeiro CM, Reece J, Putney JW, Jr. Role of the cytoskeleton in calcium signaling in $\mathrm{NIH} 3 \mathrm{~T} 3$ cells. An intact cytoskeleton is required for agonist-induced $[\mathrm{Ca} 2+] \mathrm{i}$ signaling, but not for capacitative calcium entry. J Biol Chem 1997;272:26555-61.

[14] Patterson RL, van Rossum DB, Gill DL. Store-operated Ca2+ entry: evidence for a secretion-like coupling model. Cell 1999;98:487-99.

[15] Bakowski D, Glitsch MD, Parekh AB. An examination of the secretion-like coupling model for the activation of the $\mathrm{Ca} 2+$ release-activated $\mathrm{Ca} 2+$ current $\mathrm{I}(\mathrm{CRAC})$ in RBL-1 cells. J Physiol 2001;532:55-71.

[16] Baba Y, Hayashi K, Fujii Y, Mizushima A, Watarai H, Wakamori M, et al. Coupling of STIM1 to store-operated $\mathrm{Ca} 2+$ entry through its constitutive and inducible movement in the endoplasmic reticulum. Proc Natl Acad Sci U S A 2006;103:167049. 
[17] Rosado JA, Jenner S, Sage SO. A role for the actin cytoskeleton in the initiation and maintenance of store-mediated calcium entry in human platelets. Evidence for conformational coupling. J Biol Chem 2000;275:7527-33.

[18] Rosado JA, Lopez JJ, Harper AG, Harper MT, Redondo PC, Pariente JA, et al. Two pathways for store-mediated calcium entry differentially dependent on the actin cytoskeleton in human platelets. J Biol Chem 2004;279:29231-5.

[19] Redondo PC, Harper AG, Sage SO, Rosado JA. Dual role of tubulin-cytoskeleton in store-operated calcium entry in human platelets. Cell Signal 2007;19:2147-54.

[20] Holda JR, Blatter LA. Capacitative calcium entry is inhibited in vascular endothelial cells by disruption of cytoskeletal microfilaments. FEBS Lett 1997;403:191-6.

[21] Redondo PC, Lajas AI, Salido GM, Gonzalez A, Rosado JA, Pariente JA. Evidence for secretion-like coupling involving pp60src in the activation and maintenance of store-mediated $\mathrm{Ca} 2+$ entry in mouse pancreatic acinar cells. Biochem J 2003;370:255-63.

[22] Redondo PC, Harper MT, Rosado JA, Sage SO. A role for cofilin in the activation of store-operated calcium entry by de novo conformational coupling in human platelets. Blood 2006;107:973-9.

[23] Redondo PC, Ben-Amor N, Salido GM, Bartegi A, Pariente JA, Rosado JA. Ca2+independent activation of Bruton's tyrosine kinase is required for store-mediated Ca2+ entry in human platelets. Cell Signal 2005;17:1011-21.

[24] Heemskerk JW, Feijge MA, Henneman L, Rosing J, Hemker HC. The Ca2+mobilizing potency of alpha-thrombin and thrombin-receptor-activating peptide on human platelets -- concentration and time effects of thrombin-induced $\mathrm{Ca} 2+$ signaling. Eur J Biochem 1997;249:547-55.

[25] Jardin I, Ben Amor N, Bartegi A, Pariente JA, Salido GM, Rosado JA. Differential involvement of thrombin receptors in $\mathrm{Ca} 2+$ release from two different intracellular stores in human platelets. Biochem J 2007;401:167-74.

[26] Jardin I, Redondo PC, Salido GM, Rosado JA. Phosphatidylinositol 4,5-bisphosphate enhances store-operated calcium entry through hTRPC6 channel in human platelets. Biochim Biophys Acta 2008;1783:84-97.

[27] Woodard GE, Lopez JJ, Jardin I, Salido GM, Rosado JA. TRPC3 regulates agoniststimulated $\mathrm{Ca} 2+$ mobilization by mediating the interaction between type I inositol 1,4,5-trisphosphate receptor, RACK1, and Orai1. J Biol Chem 2010;285:8045-53.

[28] De Felice FG, Velasco PT, Lambert MP, Viola K, Fernandez SJ, Ferreira ST, et al. Abeta oligomers induce neuronal oxidative stress through an $\mathrm{N}$-methyl-D-aspartate receptor-dependent mechanism that is blocked by the Alzheimer drug memantine. J Biol Chem 2007;282:11590-601.

[29] Bouaziz A, Amor NB, Woodard GE, Zibidi H, Lopez JJ, Bartegi A, et al. Tyrosine phosphorylation / dephosphorylation balance is involved in thrombin-evoked microtubular reorganisation in human platelets. Thromb Haemost 2007;98:375-84.

[30] Canizares C, Vivar N, Herdoiza M. Role of the microtubular system in platelet aggregation. Braz J Med Biol Res 1994;27:1533-51.

[31] White JG, Krumwiede M, Sauk JJ. Microtubule reassembly in surface-activated platelets. Blood 1985;65:1494-503.

[32] Parekh H, Simpkins H. The transport and binding of taxol. Gen Pharmacol 1997;29:167-72.

[33] Rosado JA, Sage SO. The actin cytoskeleton in store-mediated calcium entry. J Physiol 2000;526 Pt 2:221-9. 
[34] Rosado JA, Sage SO. Farnesylcysteine analogues inhibit store-regulated Ca2+ entry in human platelets: evidence for involvement of small GTP-binding proteins and actin cytoskeleton. Biochem J 2000;347 Pt 1:183-92.

[35] Singh BB, Liu X, Tang J, Zhu MX, Ambudkar IS. Calmodulin regulates Ca(2+)dependent feedback inhibition of store-operated $\mathrm{Ca}(2+)$ influx by interaction with a site in the C terminus of TrpC1. Mol Cell 2002;9:739-50.

[36] Mullins FM, Park CY, Dolmetsch RE, Lewis RS. STIM1 and calmodulin interact with Orai1 to induce $\mathrm{Ca} 2+-$ dependent inactivation of CRAC channels. Proc Natl Acad Sci U S A 2009;106:15495-500.

[37] McElroy SP, Drummond RM, Gurney AM. Regulation of store-operated Ca2+ entry in pulmonary artery smooth muscle cells. Cell Calcium 2009;46:99-106.

[38] Singaravelu K, Lohr C, Deitmer JW. Calcium-independent phospholipase A2 mediates store-operated calcium entry in rat cerebellar granule cells. Cerebellum 2008;7:467-81.

[39] Singaravelu K, Lohr C, Deitmer JW. Regulation of store-operated calcium entry by calcium-independent phospholipase A2 in rat cerebellar astrocytes. J Neurosci 2006;26:9579-92.

[40] Smyth JT, Dehaven WI, Bird GS, Putney JW, Jr. Ca2+-store-dependent and independent reversal of Stim1 localization and function. J Cell Sci 2008;121:762-72.

[41] Itagaki K, Kannan KB, Singh BB, Hauser CJ. Cytoskeletal reorganization internalizes multiple transient receptor potential channels and blocks calcium entry into human neutrophils. J Immunol 2004;172:601-7.

[42] Korkiamaki T, Yla-Outinen H, Koivunen J, Peltonen J. An intact actin-containing cytoskeleton is required for capacitative calcium entry, but not for ATP-induced calcium-mediated cell signaling in cultured human keratinocytes. Med Sci Monit 2003;9:BR199-207.

[43] Kawamura M, Terasaka O, Ebisawa T, Kondo I, Masaki E, Ahmed A, et al. Integrity of actin-network is involved in uridine 5'-triphosphate evoked store-operated $\mathrm{Ca} 2+$ entry in bovine adrenocortical fasciculata cells. J Pharmacol Sci 2003;91:23-33.

[44] Sabala P, Targos B, Caravelli A, Czajkowski R, Lim D, Gragnaniello G, et al. Role of the actin cytoskeleton in store-mediated calcium entry in glioma C6 cells. Biochem Biophys Res Commun 2002;296:484-91.

[45] Harper AG, Sage SO. A key role for reverse $\mathrm{Na}+/ \mathrm{Ca} 2+$ exchange influenced by the actin cytoskeleton in store-operated $\mathrm{Ca} 2+$ entry in human platelets: evidence against the de novo conformational coupling hypothesis. Cell Calcium 2007;42:606-17.

[46] Camello C, Pariente JA, Salido GM, Camello PJ. Sequential activation of different $\mathrm{Ca} 2+$ entry pathways upon cholinergic stimulation in mouse pancreatic acinar cells. J Physiol 1999;516 ( Pt 2):399-408.

[47] Jenner S, Sage SO. Two pathways for store-mediated calcium entry in human platelets. Platelets 2000;11:215-21.

[48] Jardin I, Lopez JJ, Salido GM, Rosado JA. Functional relevance of the de novo coupling between hTRPC1 and type II IP3 receptor in store-operated Ca2+ entry in human platelets. Cell Signal 2008;20:737-47.

[49] Grigoriev I, Gouveia SM, van der Vaart B, Demmers J, Smyth JT, Honnappa S, et al. STIM1 is a MT-plus-end-tracking protein involved in remodeling of the ER. Curr Biol 2008; 18:177-82.

[50] Rosado JA, Brownlow SL, Sage SO. Endogenously expressed Trp1 is involved in store-mediated $\mathrm{Ca} 2+$ entry by conformational coupling in human platelets. J Biol Chem 2002;277:42157-63. 
[51] Rosado JA, Sage SO. Activation of store-mediated calcium entry by secretion-like coupling between the inositol 1,4,5-trisphosphate receptor type II and human transient receptor potential (hTrp1) channels in human platelets. Biochem J 2001;356:191-8.

[52] Phillips AM, Bull A, Kelly LE. Identification of a Drosophila gene encoding a calmodulin-binding protein with homology to the trp phototransduction gene. Neuron 1992;8:631-42.

[53] Bauer MC, O'Connell D, Cahill DJ, Linse S. Calmodulin binding to the polybasic Ctermini of STIM proteins involved in store-operated calcium entry. Biochemistry 2008;47:6089-91.

[54] Litjens T, Harland ML, Roberts ML, Barritt GJ, Rychkov GY. Fast Ca(2+)-dependent inactivation of the store-operated $\mathrm{Ca} 2+$ current (ISOC) in liver cells: a role for calmodulin. J Physiol 2004;558:85-97. 


\section{Table 1}

Effects of colchicine and paclitaxel on the microtubular content of unstimulated and TGstimulated HEK-293 cells

\begin{tabular}{c|ccc} 
Stimulatory agent & Control & colchicine & paclitaxel \\
\hline None & $100 \pm 0$ & $47 \pm 5^{\dagger}$ & $139 \pm 4^{\dagger}$ \\
TG & $127 \pm 3^{*}$ & $51 \pm 7^{\dagger}$ & $145 \pm 5^{\dagger}$
\end{tabular}

HEK-293 cells were incubated with $30 \mu \mathrm{M}$ colchicine or $10 \mu \mathrm{M}$ paclitaxel for $30 \mathrm{~min}$ or the vehicles for the same period as controls. Cells were suspended in a $\mathrm{Ca}^{2+}$-free medium (1.2 mM EGTA added) and then treated with $1 \mu \mathrm{M}$ TG. Samples were removed $5 \mathrm{~s}$ before and 3 min after adding TG and the microtubular content was determined as described in material and methods. Values given are the microtubular content expressed as a percentage of the basal content and are presented as mean \pm S.E.M. of six separate determinations. ${ }^{*}, p<0.01$ compared with the microtubular content in non-stimulated cells. ${ }^{\dagger}, \mathrm{p}<0.05$ compared with the microtubular content in cells treated in the absence of inhibitors. 
Table 2

Effects of Cyt D and jasplakinolide on the F-actin content of unstimulated and TGstimulated HEK-293 cells

\begin{tabular}{c|ccc} 
Stimulatory agent & Control & Cyt D & jasplakinolide \\
\hline None & $100 \pm 0$ & $42 \pm 7^{\dagger}$ & $158 \pm 7^{\dagger}$ \\
TG & $141 \pm 5^{*}$ & $39 \pm 6^{\dagger}$ & $163 \pm 6^{\dagger}$
\end{tabular}

HEK-293 cells were incubated with $10 \mu \mathrm{M}$ cytochalasin $\mathrm{D}$ for $40 \mathrm{~min}, 10 \mu \mathrm{M}$ jasplakinolide for $30 \mathrm{~min}$ or the vehicles for the same period as controls. Cells were suspended in a $\mathrm{Ca}^{2+}$ free medium (1.2 mM EGTA added) and then treated with $1 \mu \mathrm{M}$ TG. Samples were removed $5 \mathrm{~s}$ before and $3 \mathrm{~min}$ after adding TG and the F-actin content was determined as described in material and methods. Values given are the F-actin content expressed as a percentage of the basal content and are presented as mean \pm S.E.M. of six separate determinations. ${ }^{*}, p<0.01$ compared with the F-actin content in non-stimulated cells. ${ }^{\dagger}, p<0.05$ compared with the Factin content in cells treated in the absence of inhibitors. 


\section{Figure legends}

Fig. 1. Effect of colchicine on TG-evoked $\mathrm{Ca}^{2+}$ entry and association between STIM1 and both Orail and TRPC1 in HEK-293 cells. (A) Fura-2-loaded HEK-293 cells $\left(2 \times 10^{6}\right.$ cells $/ \mathrm{mL}$ ) were incubated for $30 \mathrm{~min}$ in the absence or presence of $30 \mu \mathrm{M}$ colchicine. At the time of experiment $1.2 \mathrm{mM}$ EGTA was added. Cells were stimulated with $1 \mu \mathrm{M}$ TG and 3 min later $\mathrm{CaCl}_{2}(2 \mathrm{mM})$ was added to the medium to initiate $\mathrm{Ca}^{2+}$ entry. Histograms indicate $\mathrm{Ca}^{2+}$ entry in the presence or absence of colchicine, as indicated. $\mathrm{Ca}^{2+}$ entry was determined as described in the materials and methods section. Values are means \pm S.E.M. of six independent experiments; * $p<0.05$. (B and C) HEK-293 cells were preincubated in presence of $30 \mu \mathrm{M}$ colchicine or the vehicle (Control), as indicated, suspended in a $\mathrm{Ca}^{2+}$-free medium (1.2 mM EGTA added), stimulated for 3 min with $1 \mu \mathrm{M}$ TG and lysed. Whole cell lysates were incubated overnight with $2 \mu \mathrm{g} / \mathrm{mL}$ anti-STIM1 antibody and $25 \mu \mathrm{g} / \mathrm{mL}$ protein-A agarose and immunoprecipitates were subjected to $10 \%$ SDS-PAGE and subsequent Western blotting with a specific anti-Orai1 (B) or anti-TRPC1 (C) antibody. Membranes were reprobed with the anti-STIM1 antibody for protein loading control (bottom panels). The panels show results from one experiment representative of 5 others. Molecular masses indicated on the right were determined using molecular-mass markers run in the same gel. Histograms represent the quantification of STIM1-Orai1 or STIM1-TRPC1 association in non-stimulated (control) and TG-treated cells. Results are presented as arbitrary optical density units and expressed as means \pm S.E.M. $* p<0.05$, n.s., non significant. PC and PFC, primary control and primary-free control, respectively. For PC, whole cell lysates were subjected to $10 \%$ SDS/PAGE and subsequent Western blotting with the corresponding primary and secondary antibodies. For PFC, whole cell lysates were subjected to $10 \%$ 
Fig. 2. Effect of paclitaxel on TG-evoked $\mathrm{Ca}^{2+}$ entry and association between STIM1 and both Orail and TRPC1 in HEK-293 cells. (A) Fura-2-loaded HEK-293 cells $\left(2 \times 10^{6}\right.$ cells $/ \mathrm{mL}$ ) were incubated for $30 \mathrm{~min}$ in the absence or presence of $10 \mu \mathrm{M}$ paclitaxel. At the time of experiment $1.2 \mathrm{mM}$ EGTA was added. Cells were stimulated with $1 \mu \mathrm{M}$ TG and 3 min later $\mathrm{CaCl}_{2}(2 \mathrm{mM})$ was added to the medium to initiate $\mathrm{Ca}^{2+}$ entry. Histograms indicate $\mathrm{Ca}^{2+}$ entry in the presence or absence of paclitaxel, as indicated. $\mathrm{Ca}^{2+}$ entry was determined as described in the materials and methods section. Values are means \pm S.E.M. of six independent experiments; * $p<0.05$. (B and C) HEK-293 cells were preincubated in presence of $10 \mu \mathrm{M}$ paclitaxel or the vehicle (Control), as indicated, suspended in a $\mathrm{Ca}^{2+}{ }_{\text {-free medium }}$ (1.2 mM EGTA added), stimulated for 3 min with $1 \mu \mathrm{M}$ TG and lysed. Whole cell lysates were incubated overnight with $2 \mu \mathrm{g} / \mathrm{mL}$ anti-STIM1 antibody and $25 \mu \mathrm{g} / \mathrm{mL}$ protein-A agarose and immunoprecipitates were subjected to $10 \%$ SDS-PAGE and subsequent Western blotting with a specific anti-Orai1 (B) or anti-TRPC1 (C) antibody. Membranes were reprobed with the anti-STIM1 antibody for protein loading control (bottom panels). The panels show results from one experiment representative of 5 others. Molecular masses indicated on the right were determined using molecular-mass markers run in the same gel. Histograms represent the quantification of STIM1-Orai1 or STIM1-TRPC1 association in non-stimulated (control) and TG-treated cells. Results are presented as arbitrary optical density units and expressed as means \pm S.E.M. ${ }^{*} p<0.05$, n.s., non significant. HC, heavy chain of the immunoglobulin used for immunoprecipitation. 
Fig. 3. Effect of jasplakinolide on TG-evoked $\mathrm{Ca}^{2+}$ entry and association between STIM1 and both Orai1 and TRPC1 in HEK-293 cells. (A) Fura-2-loaded HEK-293 cells $\left(2 \times 10^{6}\right.$ cells $/ \mathrm{mL}$ ) were incubated for $30 \mathrm{~min}$ in the absence or presence of $10 \mu \mathrm{M}$ jasplakinolide. At the time of experiment $1.2 \mathrm{mM}$ EGTA was added. Cells were stimulated with $1 \mu \mathrm{M}$ TG and 3 min later $\mathrm{CaCl}_{2}(2 \mathrm{mM})$ was added to the medium to initiate $\mathrm{Ca}^{2+}$ entry. Histograms indicate $\mathrm{Ca}^{2+}$ entry in the presence or absence of jasplakinolide, as indicated. $\mathrm{Ca}^{2+}$ entry was determined as described in the materials and methods section. Values are means \pm S.E.M. of six independent experiments; $* p<0.05$. (B and C) HEK-293 cells were preincubated in presence of $10 \mu \mathrm{M}$ jasplakinolide or the vehicle (Control), as indicated, suspended in a $\mathrm{Ca}^{2+}$ free medium (1.2 mM EGTA added), stimulated for 3 min with $1 \mu \mathrm{M}$ TG and lysed. Whole cell lysates were incubated overnight with $2 \mu \mathrm{g} / \mathrm{mL}$ anti-STIM1 antibody and $25 \mu \mathrm{g} / \mathrm{mL}$ protein-A agarose and immunoprecipitates were subjected to $10 \%$ SDS-PAGE and subsequent Western blotting with a specific anti-Orai1 (B) or anti-TRPC1 (C) antibody. Membranes were reprobed with the anti-STIM1 antibody for protein loading control (bottom panels). The panels show results from one experiment representative of 5 others. Molecular masses indicated on the right were determined using molecular-mass markers run in the same gel. Histograms represent the quantification of STIM1-Orail or STIM1-TRPC1 association in non-stimulated (control) and TG-treated cells. Results are presented as arbitrary optical density units and expressed as means \pm S.E.M. ${ }^{*} p<0.05$, n.s., non significant. HC, heavy chain of the immunoglobulin used for immunoprecipitation.

Fig. 4. Effect of cytochalasin D on TG-evoked $\mathrm{Ca}^{2+}$ entry and association between STIM1 and both Orai1 and TRPC1 in HEK-293 cells. (A) Fura-2-loaded HEK-293 cells $\left(2 \times 10^{6}\right.$ cells $/ \mathrm{mL}$ ) were incubated for $40 \mathrm{~min}$ in the absence or presence of $10 \mu \mathrm{M}$ Cyt D. At the time of experiment $1.2 \mathrm{mM}$ EGTA was added. Cells were stimulated with $1 \mu \mathrm{M}$ TG and 3 min 
later $\mathrm{CaCl}_{2}(2 \mathrm{mM})$ was added to the medium to initiate $\mathrm{Ca}^{2+}$ entry. Histograms indicate $\mathrm{Ca}^{2+}$ entry in the presence or absence of cytochalasin $\mathrm{D}$, as indicated. $\mathrm{Ca}^{2+}$ entry was determined as described in the materials and methods section. Values are means \pm S.E.M. of six independent experiments; $* p<0.05$. (B and C) HEK-293 cells were preincubated in presence of $10 \mu \mathrm{M}$ Cyt D or the vehicle (Control), as indicated, suspended in a $\mathrm{Ca}^{2+}$-free medium (1.2 mM EGTA added), stimulated for 3 min with $1 \mu \mathrm{M}$ TG and lysed. Whole cell lysates were incubated overnight with $2 \mu \mathrm{g} / \mathrm{mL}$ anti-STIM1 antibody and $25 \mu \mathrm{g} / \mathrm{mL}$ protein-A agarose and immunoprecipitates were subjected to $10 \%$ SDS-PAGE and subsequent Western blotting with a specific anti-Orai1 (B) or anti-TRPC1 (C) antibody. Membranes were reprobed with the anti-STIM1 antibody for protein loading control. The panels show results from one experiment representative of 5 others. Molecular masses indicated on the right were determined using molecular-mass markers run in the same gel. Histograms represent the quantification of STIM1-Orai1 or STIM1-TRPC1 association in non-stimulated (control) and TG-treated cells. Results are presented as arbitrary optical density units and expressed as means \pm S.E.M. n.s., non significant. HC, heavy chain of the immunoglobulin used for immunoprecipitation.

Fig. 5. Effect of cytochalasin D on TG-evoked association between calmodulin and both Orai1 and TRPC1 in HEK-293 cells. HEK-293 cells $\left(2 \times 10^{6}\right.$ cells/mL) were preincubated in presence of $10 \mu \mathrm{M}$ Cyt D or the vehicle (Control), as indicated, and either suspended in a medium containing $1 \mathrm{mM} \mathrm{Ca}^{2+}(\mathrm{A}$ and $\mathrm{B})$ or suspended in a $\mathrm{Ca}^{2+}$-free medium $(1.2 \mathrm{mM}$ EGTA added, C and D). Cells were then stimulated for 3 min with $1 \mu \mathrm{M}$ TG and lysed. Whole cell lysates were incubated overnight with $2 \mu \mathrm{g} / \mathrm{mL}$ anti-calmodulin antibody and 25 $\mu \mathrm{g} / \mathrm{mL}$ protein-A agarose and immunoprecipitates were subjected to $10 \%$ SDS-PAGE and 
subsequent Western blotting with a specific anti-Orai1 or anti-TRPC1 antibody, as indicated. Membranes were reprobed with the anti-STIM1 antibody for protein loading control (bottom panels). The panels show results from one experiment representative of 5 others. Molecular masses indicated on the right were determined using molecular-mass markers run in the same gel. Histograms represent the quantification of calmodulin-Orai1 or calmodulin-TRPC1 association in non-stimulated (control) and TG-treated cells. Results are presented as percentage of control and expressed as means \pm S.E.M. ${ }^{*} p<0.05$, n.s., non significant. HC, heavy chain of the immunoglobulin used for immunoprecipitation. PC and PFC, primary control and primary-free control, respectively. For PC, whole cell lysates were subjected to $10 \%$ SDS/PAGE and subsequent Western blotting with the corresponding primary and secondary antibodies. For PFC, whole cell lysates were subjected to $10 \%$ SDS/PAGE and the membrane was subsequently incubated solely with the secondary antibody.

Fig. 6. Effect of calmidazolium and/or cytochalasin D on TG-evoked $\mathrm{Ca}^{2+}$ entry in HEK-293 cells. Fura-2-loaded HEK-293 cells $\left(2 \times 10^{6}\right.$ cells $\left./ \mathrm{mL}\right)$ were incubated either for $40 \mathrm{~min}$ with $10 \mu \mathrm{M}$ Cyt $\mathrm{D}$, for 10 min with $1 \mu \mathrm{M}$ calmidazolium, both or the vehicle as control. At the time of experiment $1.2 \mathrm{mM}$ EGTA was added. Cells were stimulated with $1 \mu \mathrm{M}$ TG and 3 min later $\mathrm{CaCl}_{2}(2 \mathrm{mM})$ was added to the medium to initiate $\mathrm{Ca}^{2+}$ entry. Histograms indicate $\mathrm{Ca}^{2+}$ entry in the presence or absence of $\mathrm{Cyt} \mathrm{D}$, calmidazolium or both, as indicated. $\mathrm{Ca}^{2+}$ entry was determined as described in materials and methods. Values are means \pm S.E.M. of six independent experiments; $* p<0.05$. n.s., non significant.

Fig. 7. Proposed model for cytoskeletal remodelling during SOCE in HEK-293 cells. A, in the resting state the $\mathrm{Ca}^{2+}$ stores are full and the actin filaments and microtubules, located beneath the plasma membrane, act as a cortical barrier preventing constitutive association 
between STIM1 and SOC channels. B, Cell stimulation with physiological agonists (or inhibition of $\mathrm{Ca}^{2+}$ reuptake by SERCA using thapsigargin (TG)) results in discharge of the $\mathrm{Ca}^{2+}$ stores leading to remodelling of the actin and microtubular networks to facilitate the association of STIM1 with SOC channels and the activation of SOCE. C and D, stabilization of the actin or microtubular peripheral network prevents the association of STIM1 with SOC channels and SOCE. E, Disruption of the microtubular barrier facilitates agonist (or storedepletion)-induced association events and SOCE. F, disruption of the actin filament network enhances agonist-stimulated SOCE by impairing the association of calmodulin with SOC channels. ER, endoplasmic reticulum; $\mathrm{G}$, heterotrimeric $\mathrm{G}$ protein; $\mathrm{IP}_{3}$, inositol 3,4,5trisphosphate; $\mathrm{IP}_{3} \mathrm{R}, \mathrm{IP}_{3}$ receptor; PLC, phospholipase $\mathrm{C}$; PM, plasma membrane; SOC, store-operated $\mathrm{Ca}^{2+}$ channels (i.e. Orai1 and TRPC1), 
A
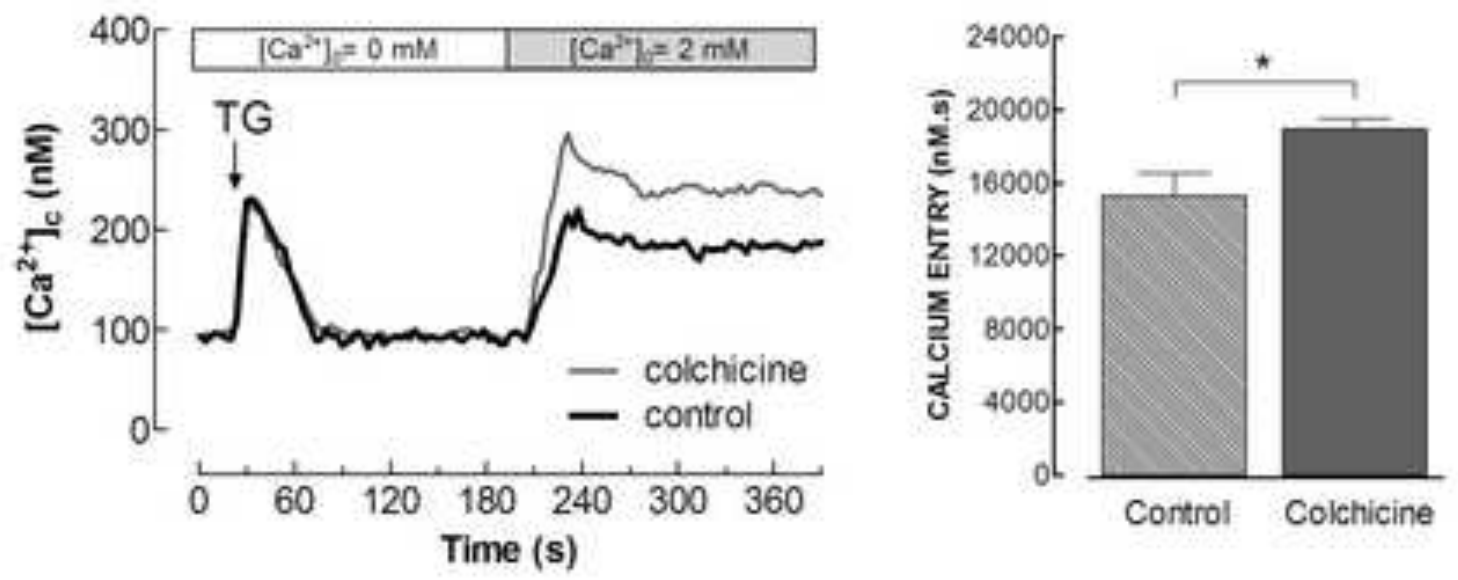

B

\section{C}
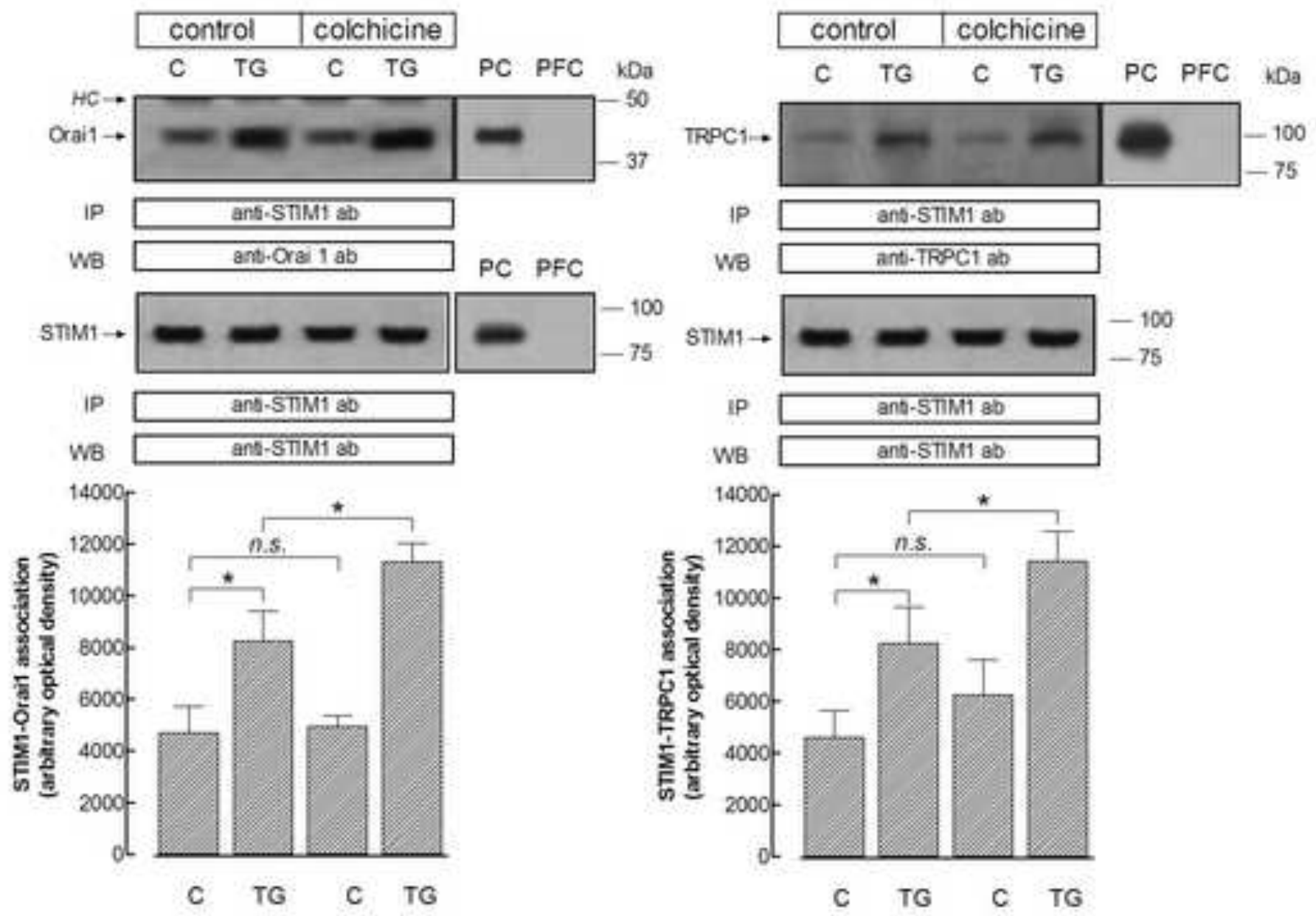

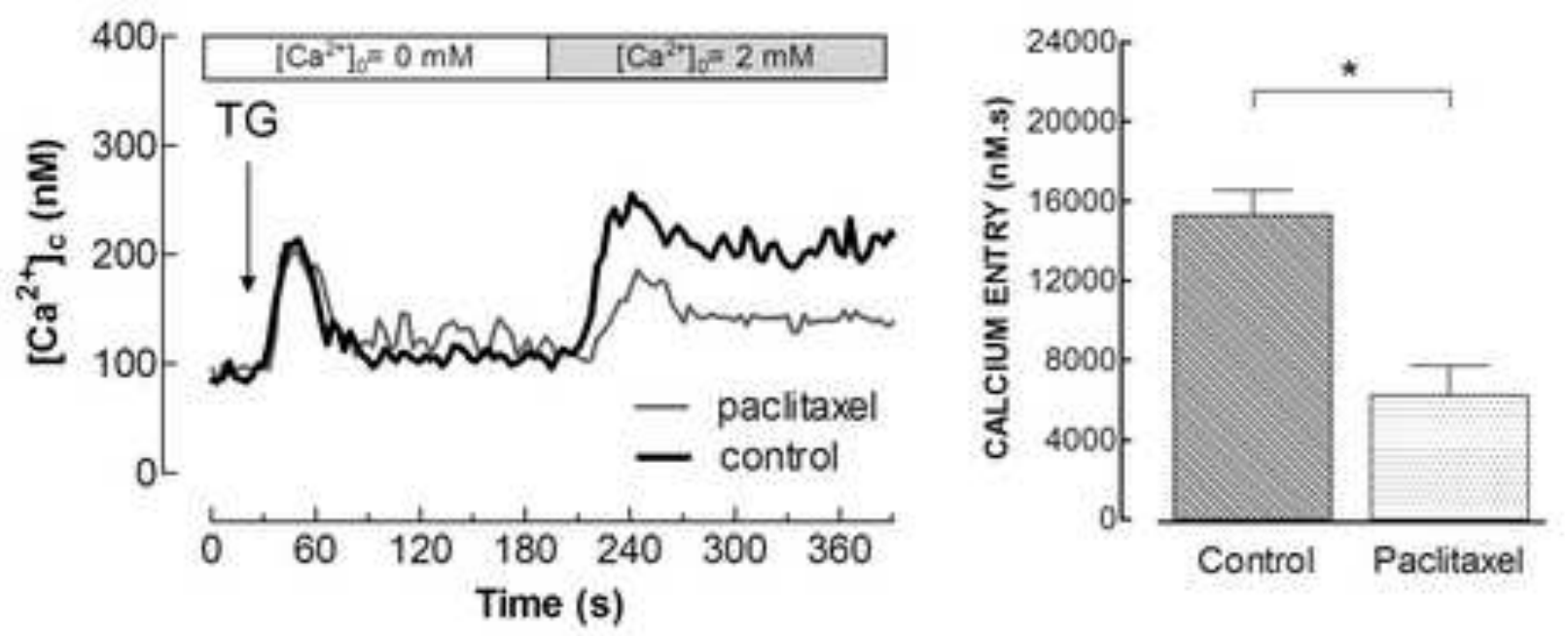

B
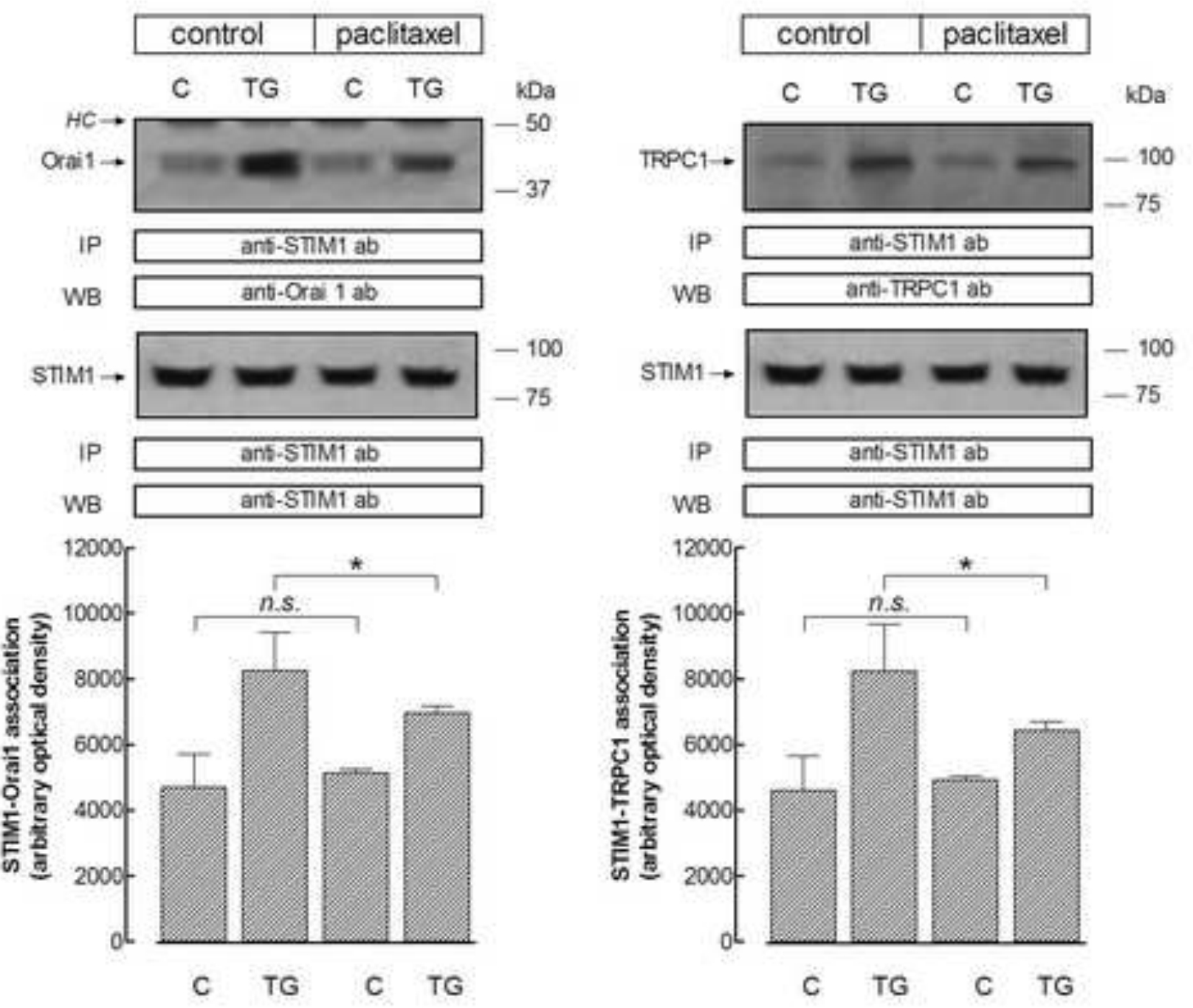
A
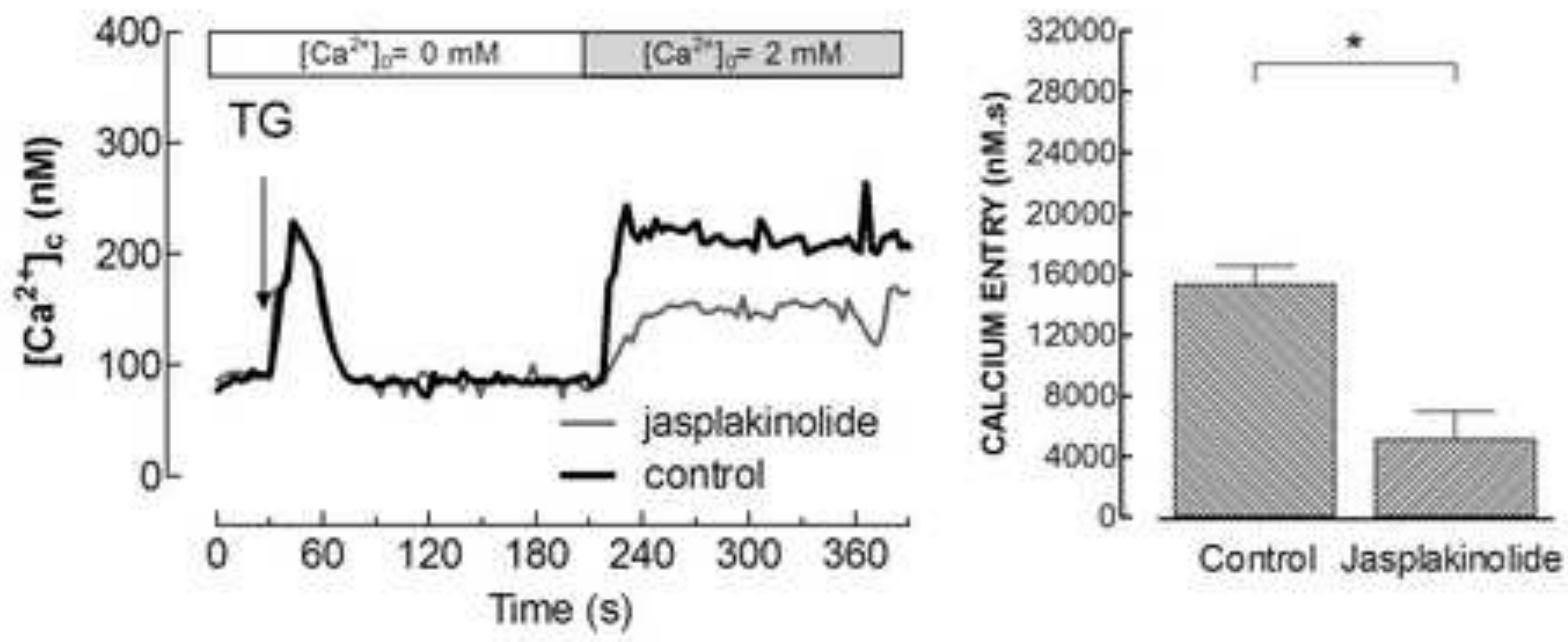

B
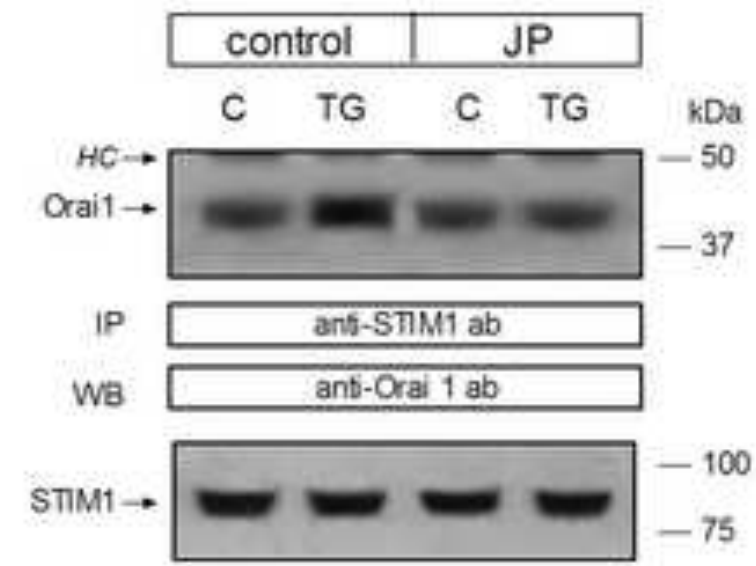

C
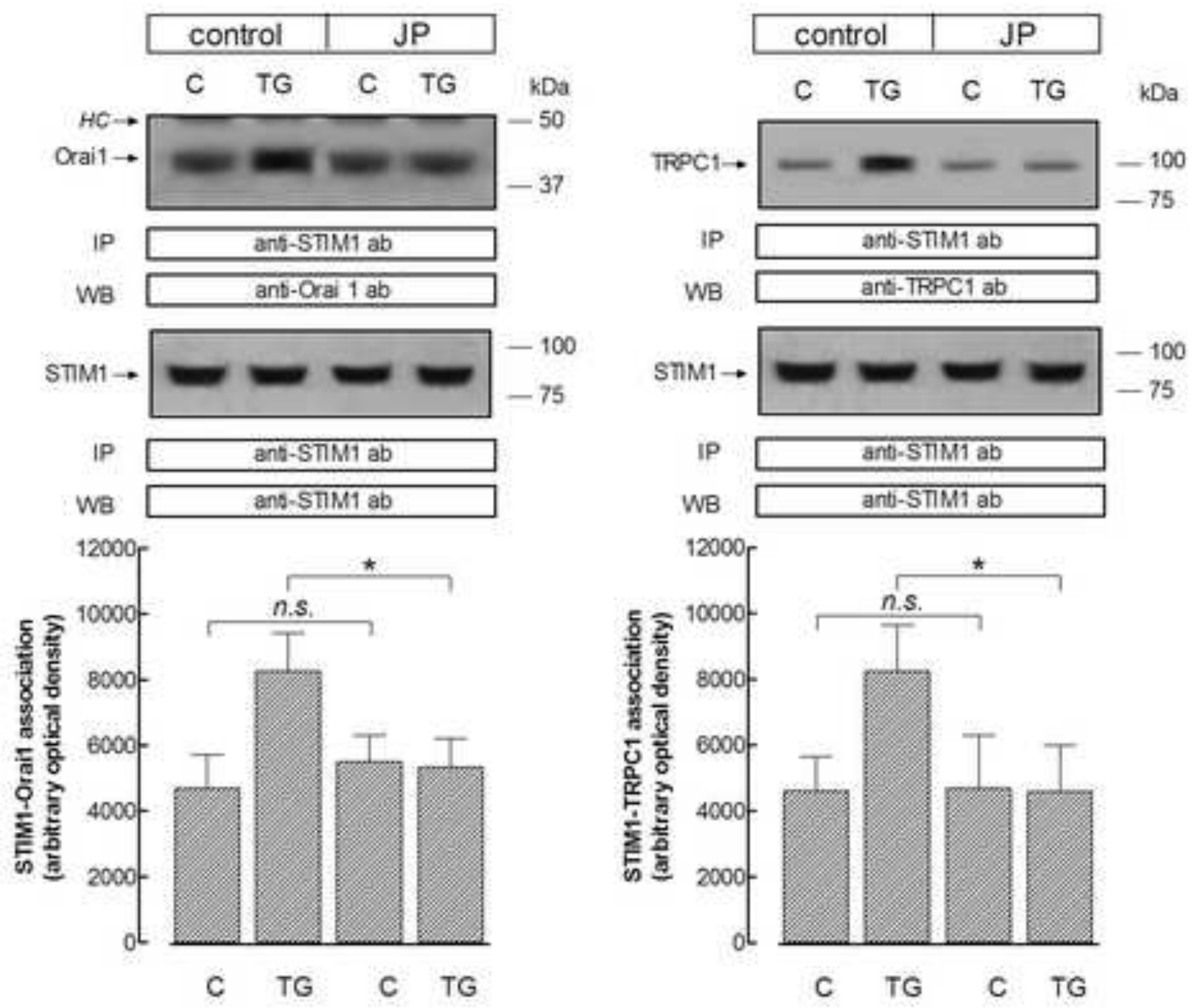


\section{A}

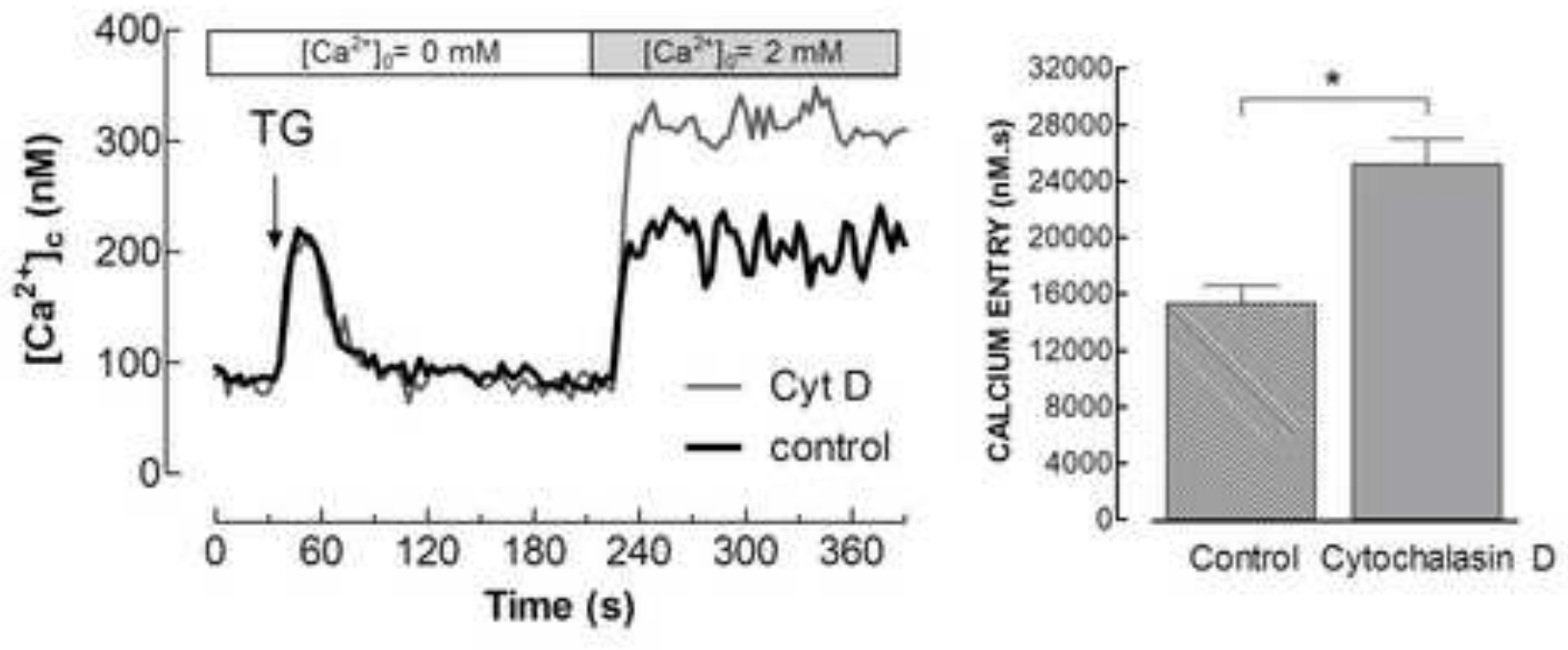

B
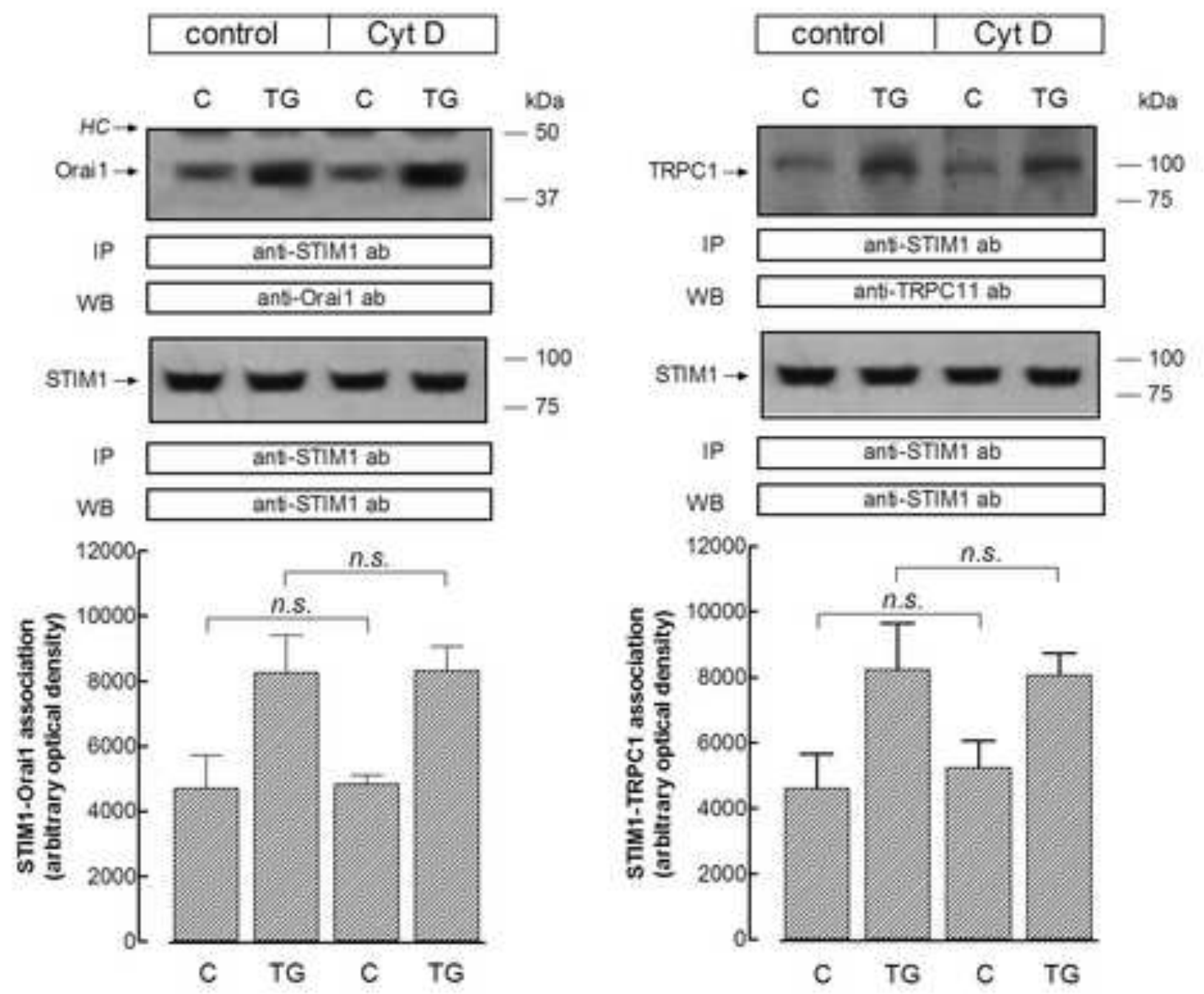
Figure 5

A
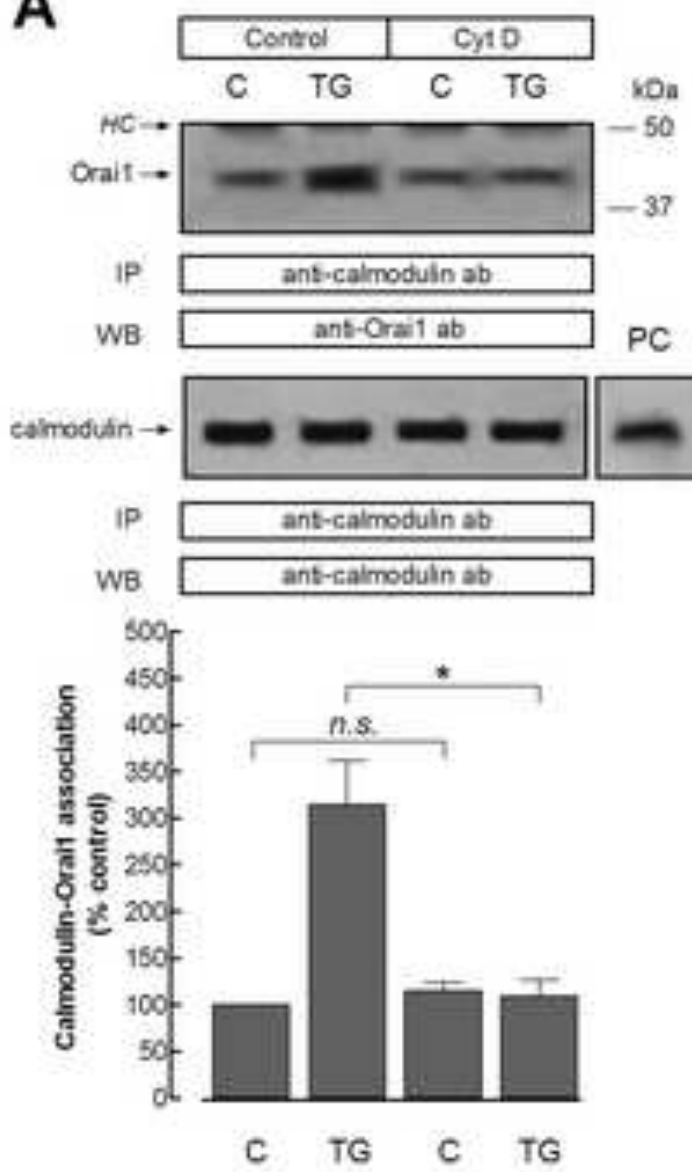

C
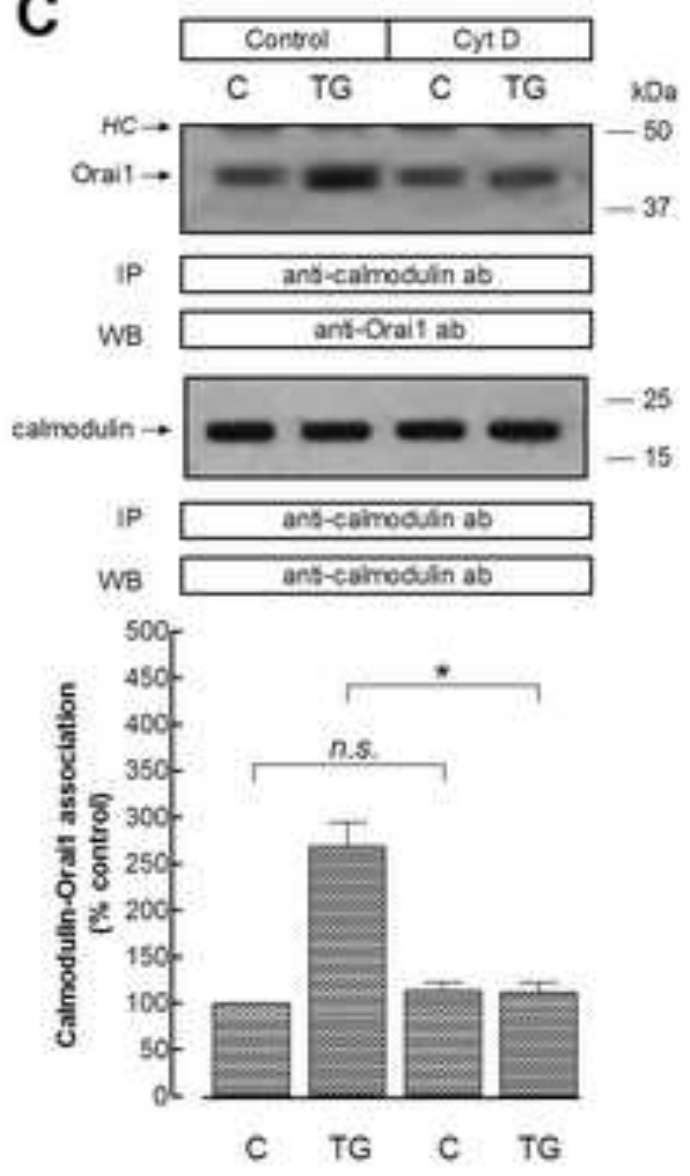

B
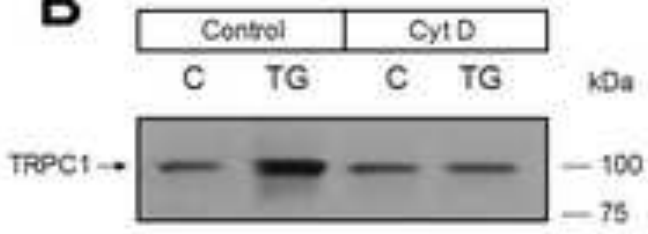

IP
WB and-caimoduin ab
WBint-mpocl ab
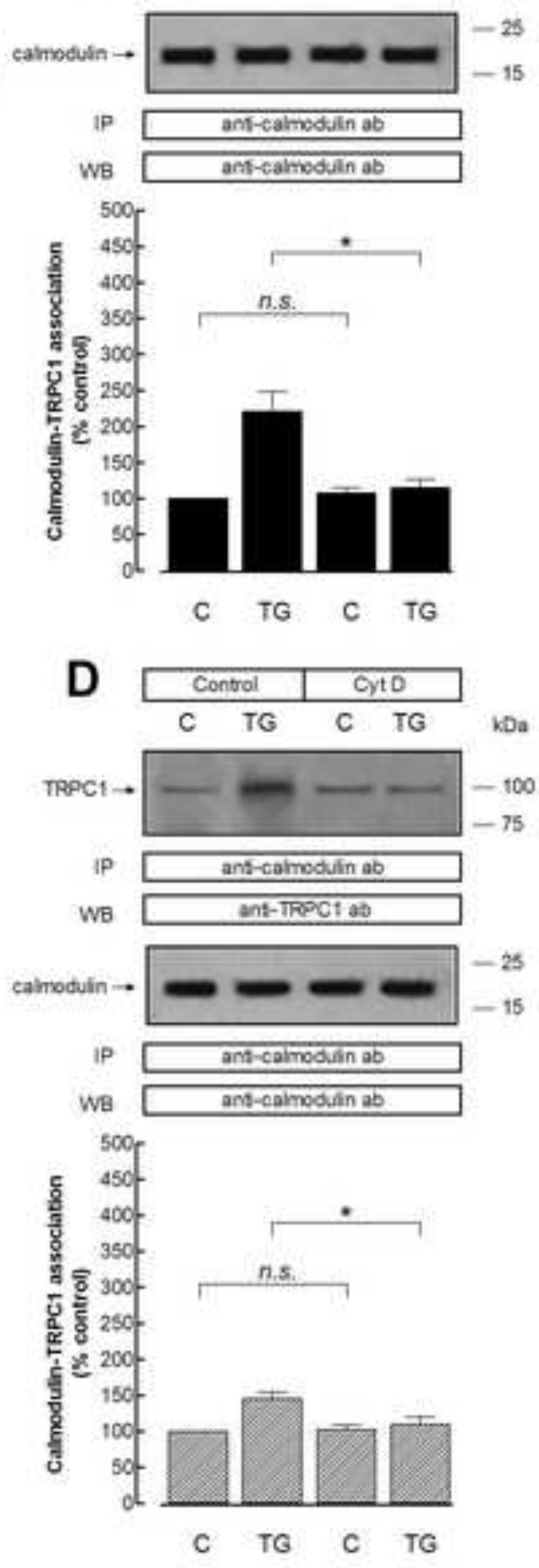

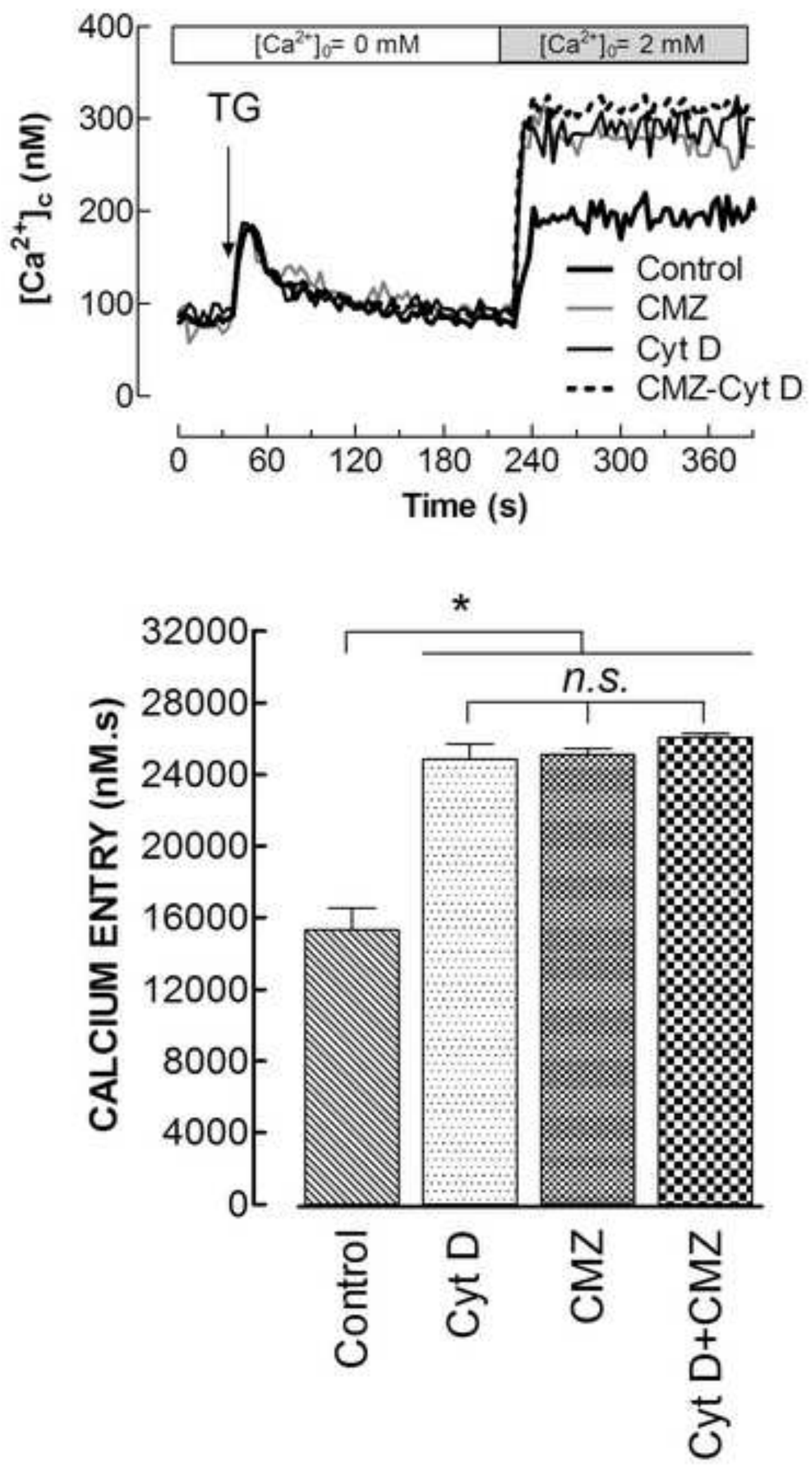

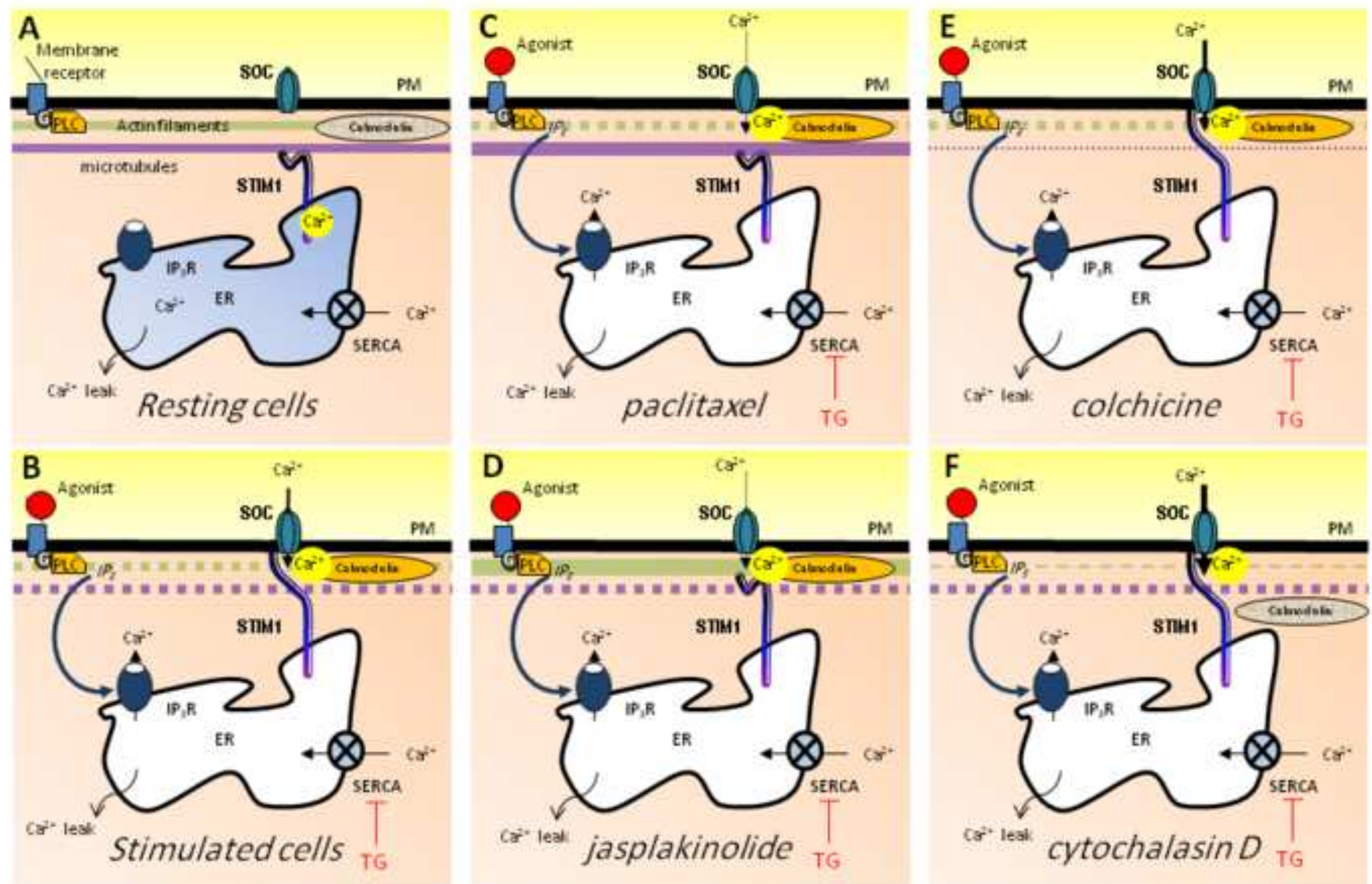


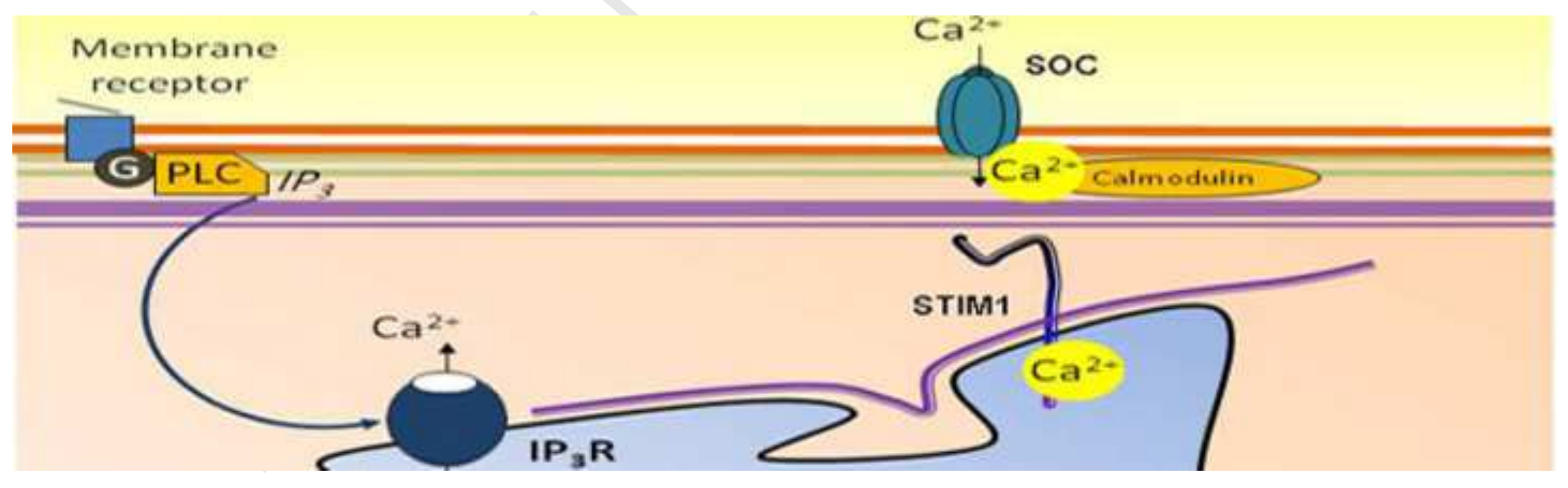

